\title{
Armored face conveyor's smooth velocity control for increased durability
}

\begin{abstract}
The article presents the concept and assumptions concerning the smooth velocity control of an armored face conveyor, and also (on this basis) the subsequent transport conveyors used in an underground coal mine. The most-important significant mathematical equations are presented, allowing us to adjust scraper movement speed to maintain a constant cross section of the transported material stream, both in the case of unidirectional and bidirectional mining. Particular attention has been paid to the zones where a longwall shearer works with a variable web; that is, when a shearer is entering into a new coal seam layer at the ends of the excavation.
\end{abstract}

Key words: scraper conveyor, armored face conveyor, velocity control, longwall, conveyor durability

\section{INTRODUCTION}

All of the scraper conveyors currently working in underground coal mine longwall systems are operating in practice with the constant movement velocity of a scraper chain (with the exception of to the use of two-speed drives for easier start-up). The variability of the longwall working conditions, technology of the mining operations, and cooperation between the machines and equipment of the longwall, maingate, and subsequent transport devices make the work of armored face conveyors (AFC), beam stage loaders (BSL), and belt conveyors characterized by high variability of efficiency; thus, the constant speed of the work of the AFC becomes unfavorable due to:

- the significant shortening of the conveyor's life, calculated in the amount of transported material from the moment of commencement of the conveyor's work to the replacement of its individual components and assemblies,

- the increased electricity consumption,

- the increased heat and noise emissions to the mine atmosphere.
The solution of this inconvenience is to change the nature of the work of the AFC from a fixed velocity to a variable one. To archive this, it is necessary to implement in new control system frequency inverters that, by using the appropriately selected control signals and algorithms, will provide such an automatic control of the conveyor chain speed to ensure a constant mostfavorable cross section of coal output on the conveyor.

The use of a frequency inverter also gives the additional advantage of the soft starting and braking of the scraper conveyor. Currently, the two-speed electric motor connected to the flexible coupling is the most-commonly-used solution for facilitating the start-up of the conveyor. There are also other technical solutions to this problem, such as fluid couplings, thyristor starters, and CST drives. More information about this topic is presented in [1].

\section{APPLICATION CONDITIONS AND STRUCTURE OF CONTROL SYSTEM}

Analysis of longwall shearer work has shown that, in the case of mining with a constant web, the appliction 
requirement for conveyor chain velocity control is the access to two external control signals; i.e., the velocity of the shearer's movement during the excavation and cleaning of the track (in the case of unidirectional mining) as well as information about the direction of the shearer's motion (movement direction consistent with or opposite to the movement of the conveyor chain).

Since the longwall shearer changes its web in the function of shearer distance to the end of the longwall during its entrance into a new coal seam layer, a third necessary control signal is the position of the shearer in the longwall for stabilizing the excavated material stream cross-section in this phase. Because of this, it is essential to obtain either the information of the present position from the shearer's internal recorders or to install external sensors and devices for measuring such a position for the proper operation of a conveyor speed control system. The concept of measuring the displacement of the shearer as it relates to the base point on the basis of the pulses from the drive system is presented in a later part of this paper.

In order to control the speed of the chain of an armored face conveyor during mining with a constant web, the use of special control algorithms is necessary that, in this case, are the dependencies determining the velocity of the chain as a function of the following parameters:
- the velocity of the longwall shearer during mining and cleaning of the path (for unidirectional mining),

- the direction of the shaper's movement relative to the transport direction of the conveyor,

- an effective shearer web,

- effective mining height,

- carbon looseness factor,

- the most-favorable cross section of the excavated material on the conveyor,

- the coefficient determining the relative value (part) of the material loaded on the longwall conveyor by the milling head during unidirectional mining.

Figure 1 shows an exemplary control system of an armored face conveyor that is suitable for use under industrial conditions. A detailed description of this system (along with details of the control software structure) is provided in [2]. The control system assembly of conveyor velocity is based on the main controller (A1), local controller (A2), frequency inverters (separately for the maingate [U1] and tailgate drives [U2]), control panel (A4), electric drives (M1-M3), and auxiliary communication and emergency brake systems. Considering the cooperation of the conveyor with other longwall equipment and subsequent transport devices, the system should also be equipped with a communication interface to connect with the beam stage loader and belt conveyor controllers as well as with the supervisory control system.

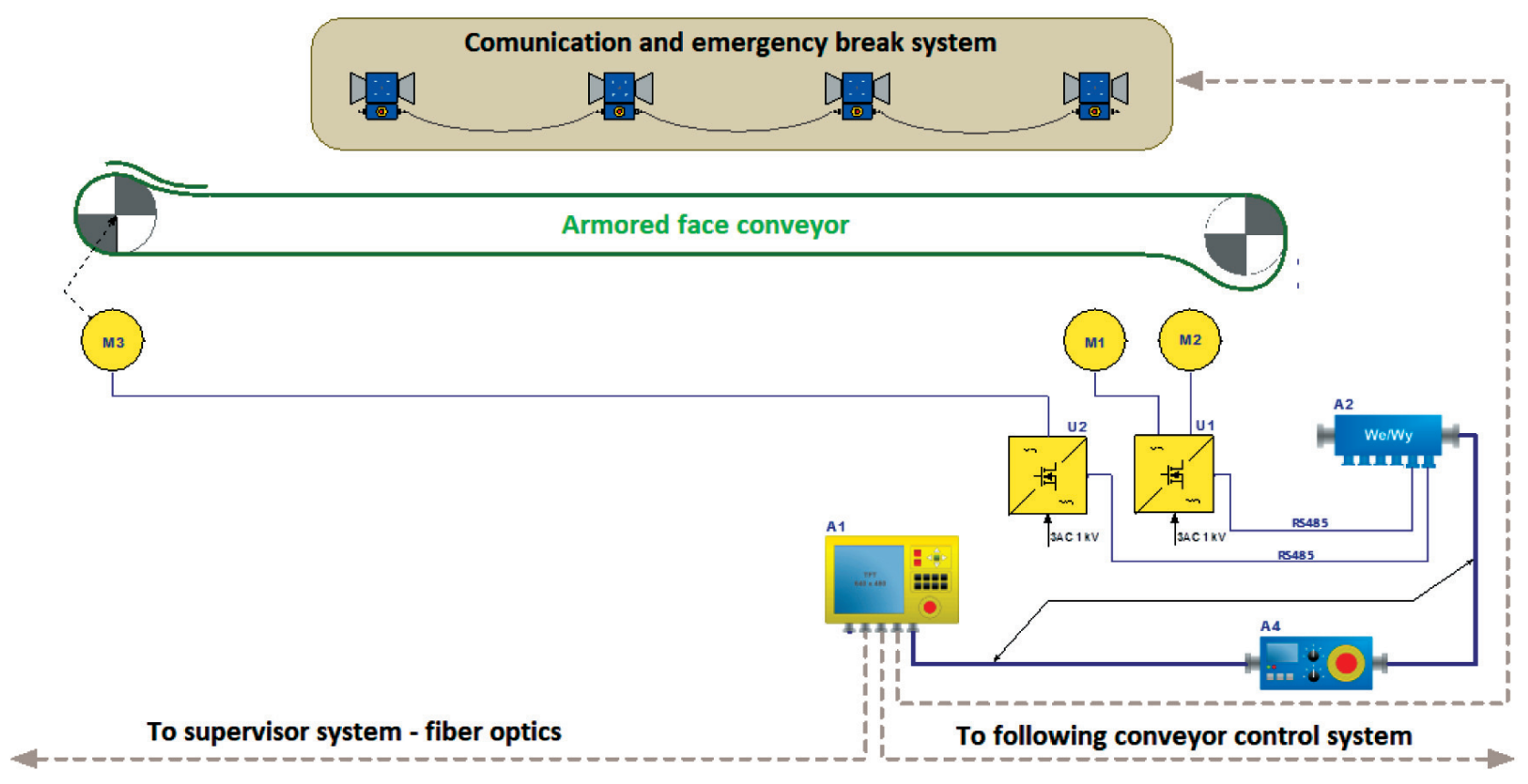

Fig. 1. Diagram of speed control system of AFC: M1, M2 - maingate motors; M3 - tailgate motor; A1 - master controller; A2 - local control; A4 - control panel; U1, U2 - frequency inverters 


\section{MONITORING OF SHEARER POSITION IN LONGWALL EXCAVATION}

Continuous information about the harvester position is required for the scraper conveyor controller for the following reasons:

- to determine the speed of the conveyor movement as a function of the haulage rate and the size of the shearer web during its entrance into a coal seam,

- it is helpful to properly control the work of the shearer to overcome the difficulties and hazards occurring in the various parts of the face,

- it can contribute to the full automation of the entire longwall complex and improvement of work safety.

Positioning of the harvester in the longwall must be accurate (without systematic error), which could increase with each harvester passing along the excavation. For this reason, the gear ratio of the shearer haulage system needed to determine the displacement from the adopted coordinate system should be reported as a theoretical relationship, taking into account the number of teeth of all gears in the gearbox and not (as commonly used) as an approximation of the gear ratio (with a gear ratio error of $0.1 \%$, one passing through the face of a $300 \mathrm{~m}$ length gives an error in the shearer position of up to $0.3 \mathrm{~m}$ ).

Displacement of the shearer from the starting position is best determined by the number of turns of the high-speed gear of the drive system. The direction of the shearer is determined by the following relationship:

$$
L_{i}=\frac{n_{i}}{i_{c}} \cdot z_{k} \cdot p[\mathrm{~m}]
$$

where:

$L_{i}$ - distance of the drive gear wheel from the beginning of the measuring reference [m],

$n_{i}-$ the number of turns of the high-speed shaft on the path of the shearer,

$z_{k}$ - number of teeth of the sharer drive wheel,

$p$ - pitch of the sharer haulage system (ladder mechanism) [m],

$i_{c}-$ overall gear ratio of the shearer drive system.

If the beginning of the measurement reference on the conveyor is adopted at the location of the shearer drive wheel axis on the maingate side, when the cutting drum finishes the cutting the upper layer of the coal seam (point K), i.e. $L_{i}=0=L_{0}$ (Fig. 2), then the shearer movement should be terminated when the K' point is reached; i.e., when the shearer travels the following distance:

$$
L_{k}=L_{S O}-A_{m r}-2 L_{r g}[\mathrm{~m}]
$$

The position of point $L_{i=0}$ at the initial stage of the sharer work (first cutting) will be at a distance from point $\mathrm{K}$ equal to $L_{0}=L_{r g}+W$.

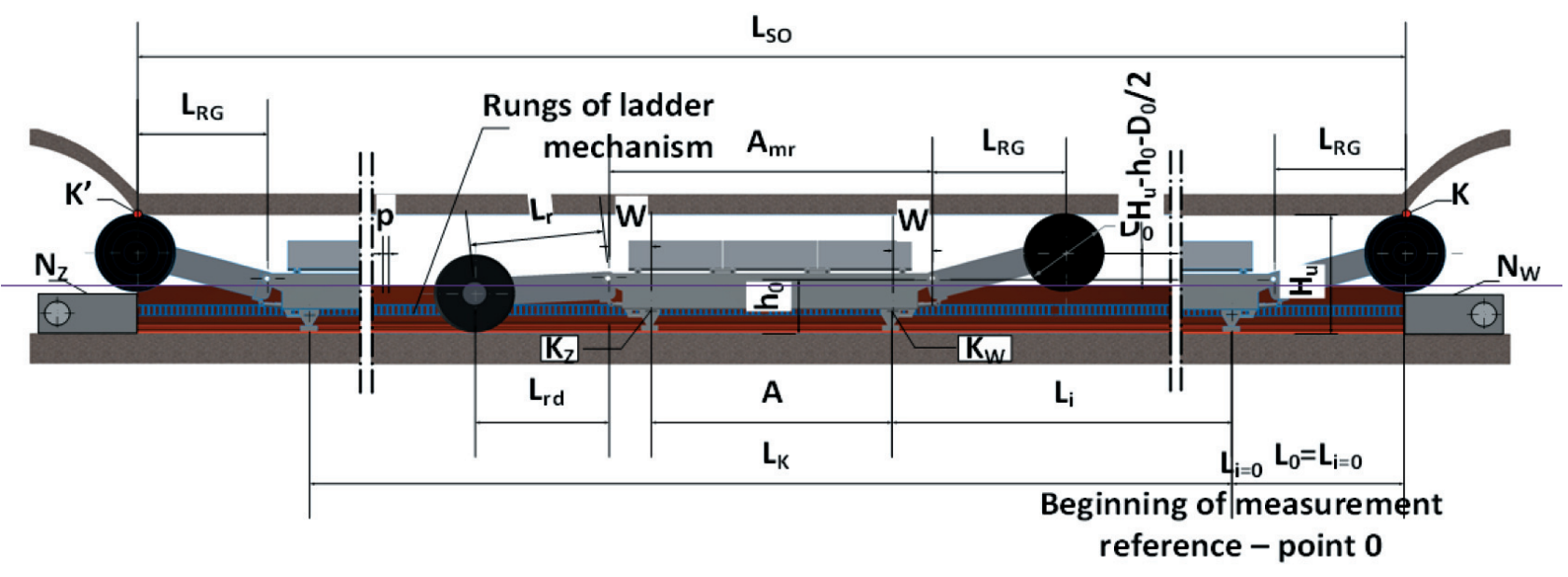

Fig. 2. Scheme for determining position of shearer when moving in line with and opposite to direction of movement of AFC: $\mathrm{Nw}$ - maingate drive, $\mathrm{Nz}$-tailgate drive, $\mathrm{Kw}, \mathrm{Kz}$-drive wheels on the shearer's maingate and tailgate sides 
For different reasons, the position of the $\mathrm{K}$ points relative to the previously adopted point $L_{i=0}$ may change; then, $L_{0}-L_{r g}+W$. Such situations may occur near the maingate, tailgate, or even on both sides when the normal or shortened pans are inserted or removed. Then, dependence (2) will then take the following form:

$$
L_{k}=L_{S O}-A_{m r}-2 L_{r g} \pm L_{d w} \pm L_{d z}[\mathrm{~m}]
$$

where:

$L_{k}$ - distance that shearer travels passing the longwall [m],

$L_{s o}$ - initial length of the longwall [m],

$A_{m r}$ - spacing between shearer arm attachment axes [m],

$L_{r g}$ - length of the shearer arm projection on horizontal axis [m],

$L_{d w}, L_{d z}$ - lengths added or subtracted due to the addition or subtraction of pans near the maingate and tailgate drives $[\mathrm{m}]$.

The length of the arm in the projection (or $L_{r g}$ ) determines the following relationship:

$$
L_{r g}=\sqrt{L_{r}^{2}-\left(H_{k}-H_{0}-0.5 D_{o}\right)^{2}}[\mathrm{~m}]
$$

where:

$H_{k}$ - maximum cutting height [m],

$H_{o}$ - the height of the shear arm from the longwall floor [m],

$D_{o}$ - the diameter of the mining drum [m].
The position of the shearer in the wall from starting point $L_{i=0}$ can be accurately determined by the number of pitches of the shearer haulage system (ladder mechanism) that it has passed:

$$
N_{i}=\frac{L_{i}}{p}=\frac{n_{i} \cdot z_{k}}{i_{c}}
$$

Miners often determine shearer position in the face approximately by specifying the number of the section of the longwall powered roof support counted from the maingate drive. In order to use this measure, the following formula can be used (Fig. 3):

$$
S_{i}=\frac{N_{i}-N_{z}}{N_{r}}+S_{z}
$$

where:

$S_{i}$ - section number indicating the approximate location of the shearer,

$N_{i}$ - the number of pitches of the shearer haulage system from point $L_{i=0}$,

$N_{z}$ - the number of pitches of the shearer haulage system from point $L_{i=0}$ to the beginning of the AFC section,

$N_{r}$ - the number of pitches of the shearer haulage system on one normal AFC section,

$S_{z}$ - number of sections of powered support at the maingate drive with a pitch different from the AFC sections.

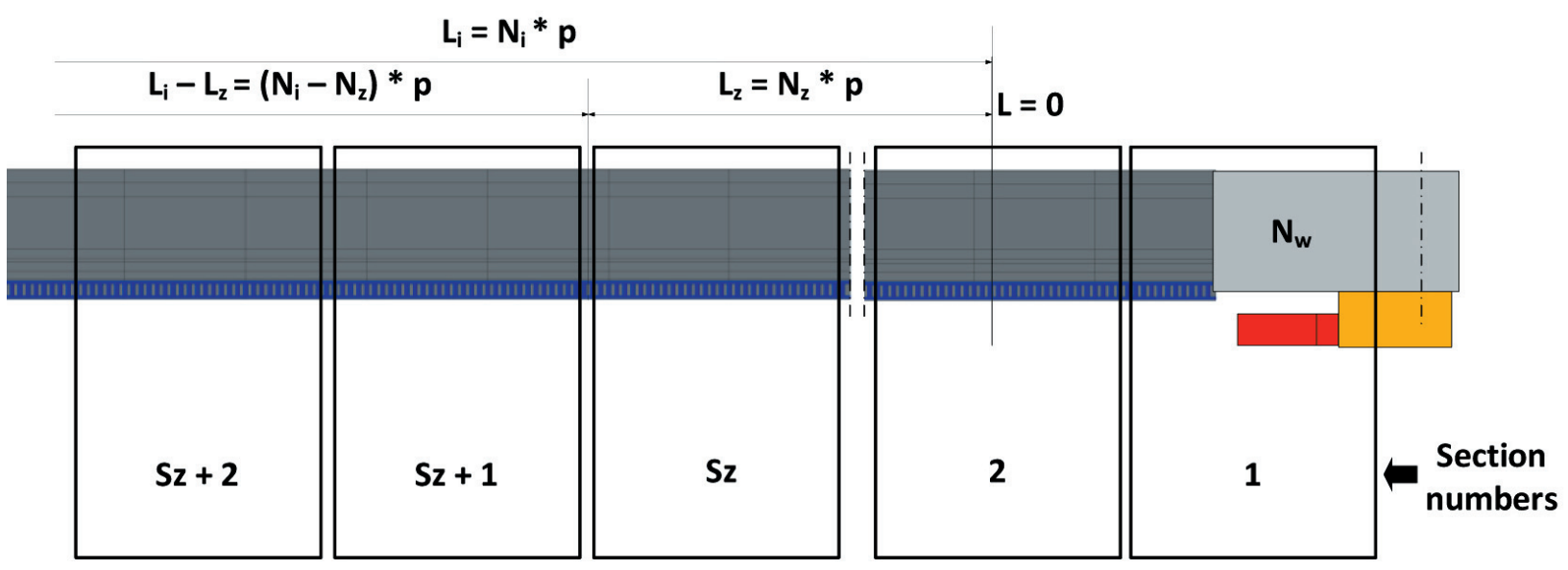

Fig. 3. Determination of approximate position of sharer in longwall by providing number of powered support sections on basis of counted pulses $\mathrm{Ni}$ 


\section{DEPENDENCIES ESSENTIAL TO CONTROLLING VELOCITY OF CONVEYOR MOVEMENT DURING OPERATION OF SHARER WITH CONSTANT WEB}

The volume of the mined coal seam and the volume (performance) of the output is described by dependence [3]:

$$
\begin{aligned}
& Q=H_{u} \cdot Z \cdot v_{k}\left[\mathrm{~m}^{3} / \mathrm{s}\right] \\
& Q_{u}=Q \cdot \Psi=H_{u} \cdot Z \cdot v_{k} \cdot \Psi\left[\mathrm{m}^{3} / \mathrm{s}\right]
\end{aligned}
$$

where:

$Q, Q_{u}$ - volume of the mined coal seam and volume of the coal output $\left[\mathrm{m}^{3} / \mathrm{s}\right]$,

$H_{u}$ - mining height [m],

$Z$ - sharer web [m],

$v_{k}$ - shearer movement velocity $[\mathrm{m} / \mathrm{s}]$,

$\Psi$ - relaxation coefficient ( $\Psi=1.35-1.4)$.

The velocity of the conveyor chain relative to the sharer is determined by the following dependence:

$$
v_{t s / k}=v_{t s} \pm v_{k}[\mathrm{~m} / \mathrm{s}]
$$

where:

$v_{t s / k}$ - velocity of the conveyor chain relative to the sharer $[\mathrm{m} / \mathrm{s}]$,

$v_{k}-$ shearer movement velocity $[\mathrm{m} / \mathrm{s}]$,

$v_{t s}-$ conveyor chain velocity $[\mathrm{m} / \mathrm{s}]$.

In formula (9), the "+" sign should be used when the shearer and chain velocity vectors have opposite directions (when the sharer moves in the direction of the tailgate), and the "-" sign when these vectors are consistently oriented in the direction of the maingate.

During bidirectional mining, it is possible to assume that the entire output is taken over by the conveyor; then, its $Q_{s}$ efficiency is equal to the following:

$$
Q_{s}=Q_{u}=H_{u} \cdot Z \cdot v_{k}\left[\mathrm{~m}^{3} / \mathrm{s}\right]
$$

By substituting the actual cross-section of the coal output on the conveyor $F_{s}$ with the equivalent rectangular cross-section (Fig. 4), the following relationship is obtained:

$$
F_{s}=b_{s} \cdot h\left[\mathrm{~m}^{2}\right]
$$

This cross-section (as a nominal $F_{s n}$ ) should be determined according to the following relationship:

$$
F_{s n}=b_{s} \cdot h_{n}=\varphi_{s} \cdot b_{s}^{2}\left[\mathrm{~m}^{2}\right]
$$

where $\varphi_{s}=(0.4-0.6)$.

Because:

$$
Q_{u}=Q_{s}=F_{s n} \cdot v_{t s / k}
$$

Hence, using dependencies (8), (9) and (12), the following formula is obtained:

$$
Q_{s}=Q_{u}=H_{u} \cdot Z \cdot v_{k} \cdot \Psi=\varphi_{s} \cdot b_{s}^{2} \cdot v_{t s / k}\left[\mathrm{~m}^{3} / \mathrm{s}\right]
$$

from which the following is obtained:

$$
\begin{aligned}
v_{t s} & =\frac{H_{u} \cdot Z \cdot v_{k} \cdot \Psi}{\varphi_{s} \cdot b_{s}^{2}}-\left( \pm v_{k}\right)= \\
& =v_{k} \cdot\left[\frac{H_{u} \cdot Z \cdot \Psi}{\varphi_{s} \cdot b_{s}^{2}}-( \pm 1)\right][\mathrm{m} / \mathrm{s}]
\end{aligned}
$$

Formula (15) for the opposite movement direction of the sharer (i.e., in the direction of the conveyor's return drive) will be as follows:

$$
v_{t s}=v_{k} \cdot\left[\frac{H_{u} \cdot Z \cdot \Psi}{\varphi_{s} \cdot b_{s}^{2}}-1\right]=k_{z p} \cdot v_{k}[\mathrm{~m} / \mathrm{s}]
$$

and for the consistent movement (i.e., in the direction of the maingate):

$$
v_{t s}=v_{k} \cdot\left[\frac{H_{u} \cdot Z \cdot \Psi}{\varphi_{s} \cdot b_{s}^{2}}+1\right]=k_{z z} \cdot v_{k}[\mathrm{~m} / \mathrm{s}]
$$

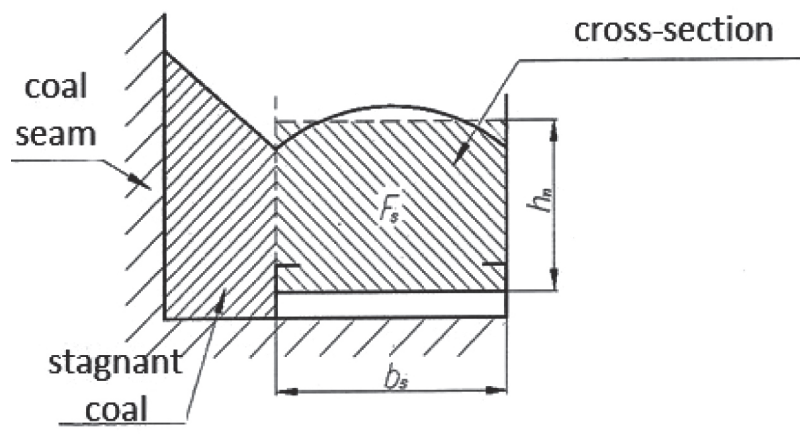

Fig. 4. Real and substitutive output cross-section on conveyor base plate 
When the shearer is mining unidirectionally, the part of the excavated material remains at the ramp plate of the conveyor. Then, the efficiency of the coal loaded by the shearer on the conveyor $Q_{s j}$ determines the following formula:

$$
Q_{s j}=Q_{u} \cdot k_{u}=k_{u} \cdot H_{u} \cdot Z \cdot \Psi \quad\left[\mathrm{m}^{3} / \mathrm{s}\right]
$$

and the efficiency of loading coal from the ramp late to the conveyor $Q_{r}$ will equal:

$$
Q_{r}=Q_{u}\left(1-k_{u}\right)\left[\mathrm{m}^{3} / \mathrm{s}\right]
$$

where $k_{u}$ in formulas (18) and (19) is the coefficient determining the relative value (share) of the coal loaded on the conveyor during the mining.

In the same way as for bidirectional machining, the appropriate dependencies can be derived to control the movement velocity of the conveyor.

When the shearer cuts the coal in a direction consistent to the conveyor's chain movement (in the direction of the maingate), the following relationship is obtained:

$$
v_{t s}=v_{k} \cdot\left[\frac{k_{u} \cdot H_{u} \cdot Z \cdot \Psi}{\varphi_{s} \cdot b_{s}^{2}}+1\right]=k_{1 z} \cdot v_{k}[\mathrm{~m} / \mathrm{s}]
$$

and while working in the opposite direction:

$$
v_{t s}=v_{k} \cdot\left[\frac{k_{u} \cdot H_{u} \cdot Z \cdot \Psi}{\varphi_{s} \cdot b_{s}^{2}}-1\right]=k_{1 p} \cdot v_{k}[\mathrm{~m} / \mathrm{s}]
$$

During the return of the shearer, the excavated material is loaded from the ramp plate. The dependencies on the $v_{t s}$ are as follows:

- for consistent movement:

$$
\begin{aligned}
v_{t s} & =v_{k} \cdot\left[\frac{\left(1-k_{u}\right) \cdot H_{u} \cdot Z \cdot \Psi}{\varphi_{s} \cdot b_{s}^{2}}+1\right]= \\
& =k_{1 z p} \cdot v_{k}[\mathrm{~m} / \mathrm{s}]
\end{aligned}
$$

- for opposite movement:

$$
\begin{aligned}
v_{t s} & =v_{k} \cdot\left[\frac{\left(1-k_{u}\right) \cdot H_{u} \cdot Z \cdot \Psi}{\varphi_{s} \cdot b_{s}^{2}}-1\right]= \\
& =k_{1 p o} \cdot v_{k}[\mathrm{~m} / \mathrm{s}]
\end{aligned}
$$

\section{DEPENDENCIES ESSENTIAL TO CONTROLLING VELOCITY OF CONVEYOR MOVEMENT DURING MINING OF LEFTOVER COAL LAYER}

According to Figure 5, the thickness of the leftover layer equals $H=H_{u}-D_{o}=k_{s u} \cdot H_{u}$. In the same manner as in point 3 , the dependence on the $v_{t s}$ in the case of the leftover layer cutting by the maingate is obtained as [2]:

$$
v_{t s}=v_{k} \cdot\left[\frac{k_{s u} \cdot H_{u} \cdot Z \cdot \Psi}{\varphi_{s} \cdot b_{s}^{2}}-1\right]=k_{2 p}^{\prime} \cdot v_{k}[\mathrm{~m} / \mathrm{s}]
$$

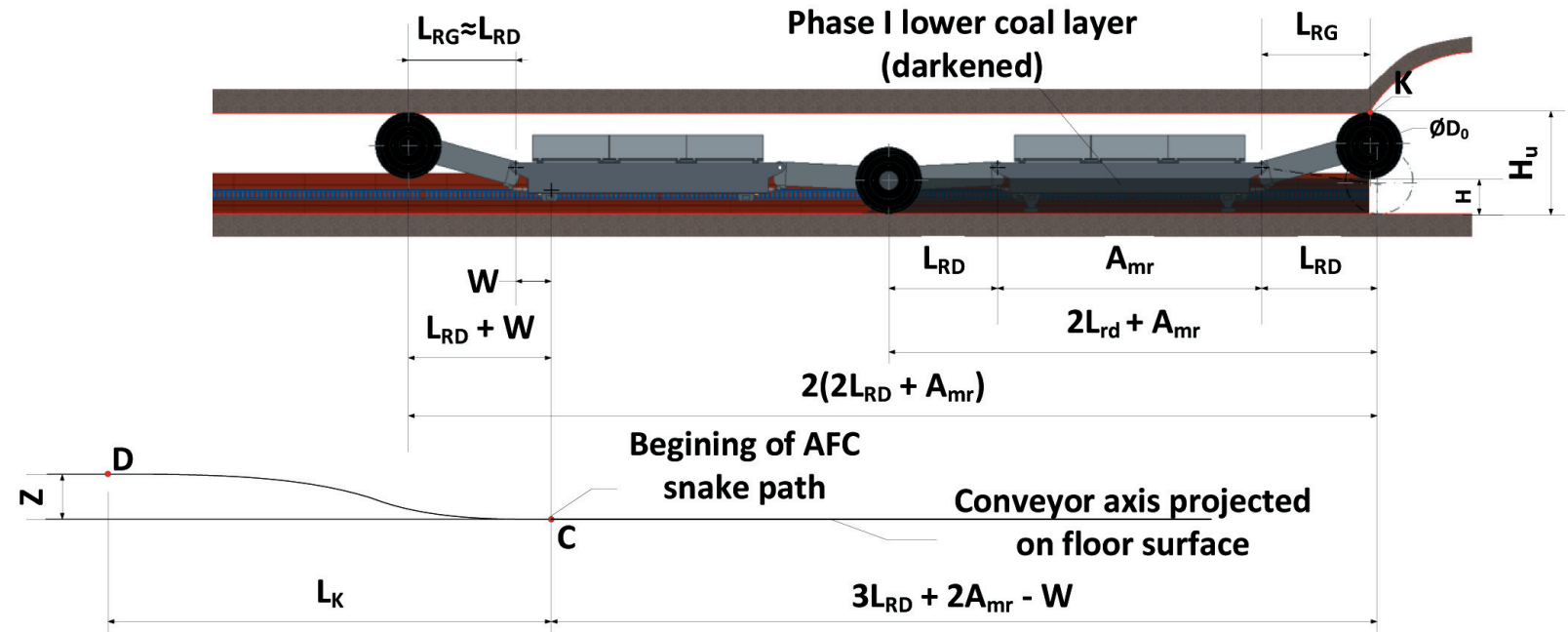

Leftover for cutting from Phase I lower coal layer (darkened)

\section{(1)}

Fig. 5. Shearer path during cutting of leftover coal layer and position of upper cutting drum at moment of shearer entrance to snake part of AFC 
and the same way at the leftover cutting by the tailgate:

$$
v_{t s}=v_{k} \cdot\left[\frac{k_{s u} \cdot H_{u} \cdot Z \cdot \Psi}{\varphi_{s} \cdot b_{s}^{2}}+1\right]=k_{2 z}^{\prime} \cdot v_{k}[\mathrm{~m} / \mathrm{s}]
$$

where $k_{s u}=H / H_{u}$ is the relative thickness of the leftover lower coal layer.

\section{DEPENDENCIES ESSENTIAL TO CONTROL VELOCITY OF CONVEYOR MOVEMENT DURING MINING WITH VARIABLE WEB}

Shearer passing through a snake part of the conveyor (which implies a variable cutting web) can be divided into three simplified phases. For example, when the harvester is driven in the area close to the maingate in Phase 1 (i.e., when drive wheel $K_{z}$ passes from point $\mathrm{C}$ to $\mathrm{C}_{1}{ }^{\prime}$, at which wheel $K_{z}$ moves in the direction of the coal seam by about $0.25 \mathrm{Z}$ ), the shearer will move by $0.35 L_{k}$ (Fig. 6). During this movement, the shearer velocity can be the same as during the cutting of the leftover layer.

In phase 2 (which is on the path from point $\mathrm{C}_{1}{ }^{\prime}$ to $\mathrm{C}_{2}$ ), the velocity of the shearer changes linearly depending on the position of the shearer on the curvature. At point $\mathrm{C}_{2}$ (after passing a distance of $0.48 L_{k}$ ), the shearer will gain velocity corresponding to the full web. For this phase, after transforming dependence (1) and using the fact that the variable velocity of the shearer occurs at $0.48 L_{k}$, the following formula is obtained:

$$
v_{t s}=v_{t C_{1}^{\prime}}+\frac{\Delta v_{t s}}{n_{C^{\prime}-C_{2}}}\left(n_{1}-n_{C^{\prime}}\right)[\mathrm{m} / \mathrm{s}]
$$

Considering that:

$$
\Delta v_{t s}=\left(k_{z p}^{\prime}-k_{z p}\right) \cdot v_{k}[\mathrm{~m} / \mathrm{s}]
$$

and:

$$
n_{C_{1}^{\prime}-C_{2}}=\frac{i_{C} \cdot 0,48 L_{k}}{z_{k} \cdot p}
$$

and by substituting form (29), equation (30) is obtained:

$$
\begin{aligned}
& k_{j}=\frac{\left(k_{z p}^{\prime}-k_{2 p}^{\prime}\right)}{\frac{i_{C} \cdot 0,48 L_{k}}{z_{k} \cdot p}} \\
& v_{t s}=\left(k_{z p}^{\prime}+k_{j}\right) \cdot\left(n_{i}-n_{C_{1}}\right)[\mathrm{m} / \mathrm{s}]
\end{aligned}
$$

In phase 3 , from points $\mathrm{C}_{2}$ to $\mathrm{D}$; i.e., at a distance of $0.17 L_{k}$ and later at a distance of $\left(l_{r d}+A+W\right)$, the $v_{t k}$ should be like during mining with a constant web (i.e., $v_{t k}=k_{2 p} \cdot v_{k}$ ). The movement of the shearer at distance $\left(l_{r d}+A a+W\right)$ is necessary so that the $K_{w}$ wheel reaches the end of the snake section and reaches point D (Fig. 6). During the shearer movement through the snake section, the conveyor on the side of the tailgate drive should be progressively pushed to

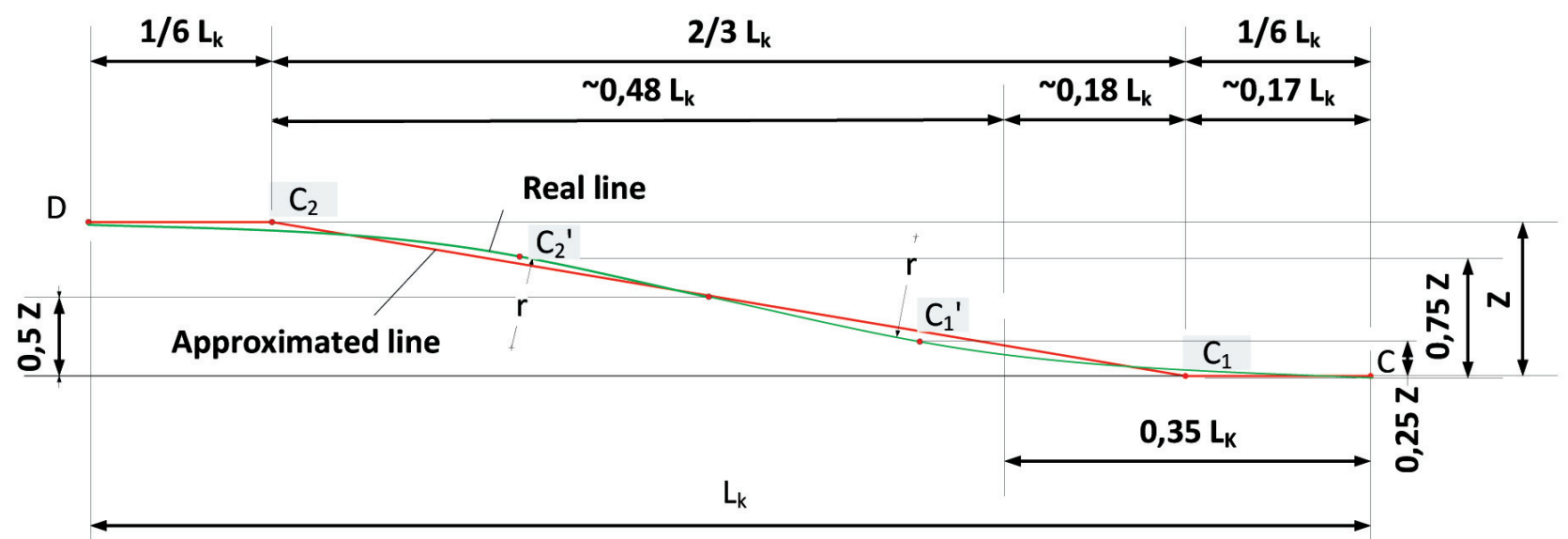

Fig. 6. Replacement of real curvature line of conveyor on snake section with straight line $C_{1}-C-{ }_{1}-C_{2}$ 
the front of the face so that, when point $\mathrm{D}$ is reached, the entire length of the conveyor curvature is already straight.

\section{CONTROL OF FOLLOWING CONVEYORS IN COAL OUTPUT TRANSPORT CHAIN}

On the basis of the velocity control of the armored face conveyor, it is very easy to initiate the velocity control beam stage loader (BSL) and further elements of the coal output transport chain. In the case of the beam stage loader (Fig. 7) [4], the control sig- nal for its chain velocity will be the movement rate of the longwall AFC.

The relationship between the velocity of movement of the AFC and the beam stage loader is linear and proportional according to the following formula:

$$
v_{t p}=k_{p} \cdot v_{t s}[\mathrm{~m} / \mathrm{s}]
$$

where:

$v_{t p}-$ velocity of beam stage loader chain $[\mathrm{m} / \mathrm{s}]$,

$v_{t s}-$ velocity of armored face conveyor $[\mathrm{m} / \mathrm{s}]$,

$k_{p}$ - beam stage loader velocity rate in relationship to the AFC.

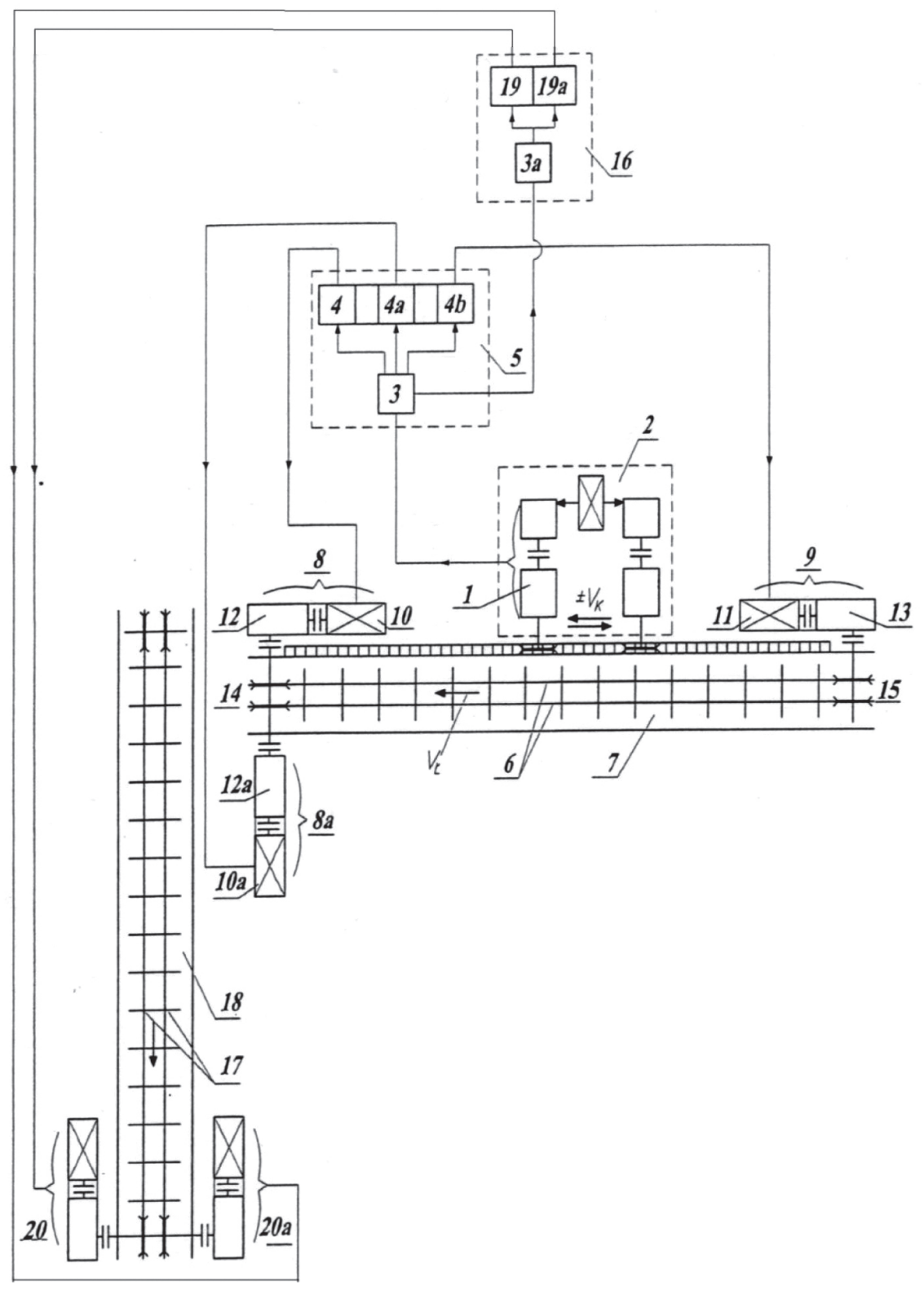

Fig. 7. Schematic of BSL velocity control system: 1 - transmission of shearer haulage system; 2 - sharer haulage unit; 3 - AFC velocity controller; $3 a-B S L$ velocity controller; 4, 4a, 4b-frequency inverters; 6 - AFC scraper chain; 7 -AFC; 8, 8a, 9 - drive units; 10, 10a, 11 - drive motors; 12, 12a, 13 - gear units; 14, 15 - star pulleys; 16 - BSL control unit; 17 - BSL scraper chain; 18 - BSL; 19, 19a-BSL frequency inverters; 20, 20a-BSL drive units 
Coefficient $k_{p}$ is determined by equation (32):

$$
k_{p}=\frac{\varphi_{s} \cdot b_{s}^{2}}{\varphi_{p} \cdot b_{p}^{2}}
$$

where:

$b_{s}$ - the width of the AFC base plate [m],

$b_{p}$ - the width of the BSL base plate [m],

$\varphi_{s}-$ the relative height of the equivalent rectangular output stream on the AFC $\left(\varphi_{\mathrm{s}}=0.4-0.6\right)$,

$\varphi_{p}$ - the relative height of the equivalent rectangular output stream on the BSL $\left(\varphi_{\mathrm{s}}=0.3-0.5\right)$.

Coefficients $\varphi_{s}$ and $\varphi_{p}$ are determined by the following equations:

$$
\begin{gathered}
\varphi_{s}=\frac{h_{n s}}{b_{s}} \\
\varphi_{p}=\frac{h_{n p}}{b_{p}}
\end{gathered}
$$

In formulas (33) and (34), the constants are denoted by the following:

$h_{n s}$ - the nominal height of the equivalent rectangular output of the AFC [m],

$h_{n p}$ - the nominal height of the equivalent rectangular output of the BSL [m].
The motion velocity of the belt conveyor receiving a coal output stream from the BSL should be based on the BSL scraper movement rate (Fig. 8), which depends on the movement speed of the AFC scraper chain. Direct use of the signal from the shearer is not advisable to control the velocity of the belt conveyor (just like in the case of the BSL velocity control) because it would require us to synthesize new complex control algorithms that incorporate both consistent and opposite mining directions during bi- and uni-directional cutting.

Using the signal from the BSL is much simpler because the belt speed is determined by the simple equation (35) in this case:

$$
v_{t}=\frac{\varphi_{p} \cdot b_{p}^{2}}{k_{a} \cdot F_{n}} \cdot v_{t p}=k_{t} \cdot v_{t p}[\mathrm{~m} / \mathrm{s}]
$$

where:

$v_{t}-$ belt conveyor velocity $[\mathrm{m} / \mathrm{s}]$,

$F_{n}$ - nominal cross-section of the output on belt conveyor [m],

$b_{p}$ - BSL base plate width [m],

$v_{t p}-$ BSL velocity $[\mathrm{m} / \mathrm{s}]$,

$\varphi_{p}-$ the relative height of the equivalent rectangular output stream on the BSL,

$k_{a}$ - the conveyor belt velocity coefficient relative to the BSL.

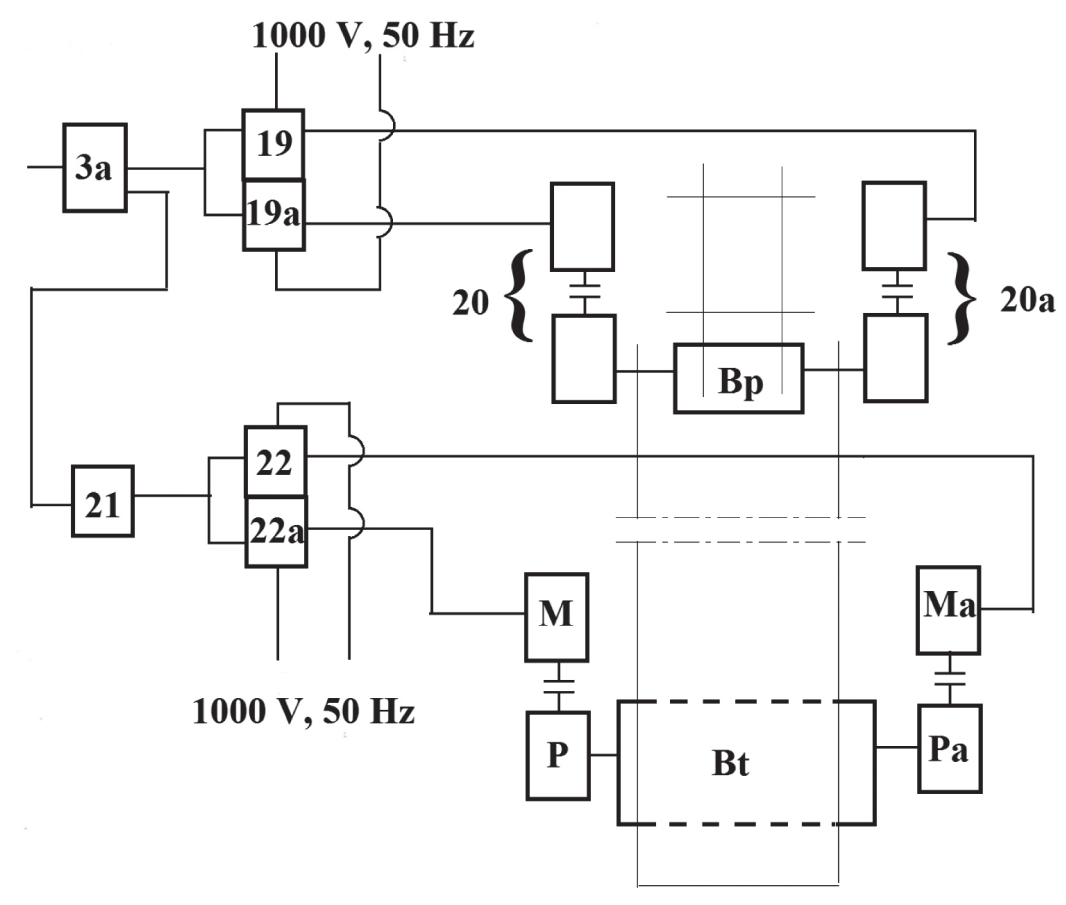

Fig. 8. Schematic of belt conveyor velocity control (in reference to scheme from Fig. 7): $3 a-B S L$ controller; 19, 19a-BSL frequency inverters; 20, 20a-BSL drive units; 21 - belt conveyor controller (local); 22, 22a-belt conveyor frequency inverters; $M, M a$ - belt conveyor motors; P, Pa - belt conveyor gear units; Bp, Bt - BSL star pulley and belt conveyor drive drum 
The presented method of belt conveyor velocity control can be further extended to control all of the following belt conveyors in the transport chain. This way of velocity control can also be applied to control the main (collective) conveyors; however, with the current model of underground coal exploitation in Poland (implying the simultaneous operation of a maximum of three longwalls from different regions and underground levels of mining), the consideration of such control of the conveyor belt operation is aimless.

\section{FINAL REMARKS AND SUMMARY}

The dependences and formulas shown in this article allow for such a velocity control of the armored scraper conveyor that, during its operation, the crosssectional area of the excavated material at the conveyor pans is approximately constant. Its optimum value for each face excavation should be optimally determined with regards to the exploitation conditions, including the clearance under the shearer, size of the output material, width of the conveyor, adopted mining system (uni- or bi-directional), and mining and geological conditions. Relative, substitutive output height $\mathrm{h}$ as related to base plate width $\mathrm{h} / \mathrm{bs}$ should not exceed 0.6 , because the motion resistance then increases too greatly; moreover, the average movement rate of the dragged coal significantly decreases with respect to the scraper chain velocity, which makes transport less energy-efficient and less effective.

The conveyor speed control algorithm can be implemented in different ways. It can be a single computer program covering all stages of the sharer work in uni- and bi-directional systems or separate ones for both of these cutting methods. It is also desirable for the shearer operator to be able to manually control both the shearer and the AFC in case of automatic velocity control system failure.

An important issue that needs to be taken into account during the creation of conveyor speed control programs is the AFC velocity when the shearer is stopped and the coal output system is still working. On the basis of the equations previously presented, it would have been necessary to stop the AFC; such a sudden stop does not appear to be advantageous due to reduced miner safety and the delay created. Such frequent stops reduce the effective working time of the longwall and decrease productivity. For this reason, it seems desirable that the conveyor not stop completely but rather work continuously at approximately $10 \%$ of the nominal speed. The time interval of this movement could also vary according to local conditions.

Implementation of the presented velocity control system of an AFC enables the easy control of the movement speed of further conveyors in the transport chain. However, this requires the use of variable velocity drives in each transport device in such a chain.

Preliminary analyses based on practical observations tend to suggest that the introduction of the proposed control system can increase the durability of the conveyor components (measured by the amount of transported coal until end of each component's technical life) to about $25 \%$. It is also expected to reduce transport energy consumption at a similar level.

\section{Acknowledgement}

Publication developed within INNOTECH-K1/IN1/ 158914/NCBR/12 research project „Energy-saving conveyor velocity control system to increase their durability," founded by the Polish National Center for Research and Development NCBiR.

\section{References}

[1] Mendyka P.: Układy rozruchowe ścianowych przenośników zgrzebłowych, "Napędy i Sterowanie" 2014, 16, 7/8: 138-144.

[2] Gospodarczyk P., Stopka G., Mendyka P.: Projekt $i$ badania ścianowego przenośnika zgrzebłowego o zmiennej prędkości ru$c h u$, w Monografia "Mechanizacja, automatyzacja i robotyzacja w górnictwie”, Centrum Badań i Dozoru Górnictwa Podziemnego, Kraków - Lędziny 2014: 223-233.

[3] Suchoń J.: Górnicze przenośniki zgrzebłowe. Teoria, badania i eksploatacja, Instytut Techniki Górniczej, Gliwice 2012.

[4] Suchoń J., Tytko S.: Nowe propozycje RFM "RYFAMA" S.A. $w$ zakresie budowy $i$ sterowania ruchem ścianowych przenośników zgrzebłowych, V Szkoła Mechanizacji i Automatyzacji Górnictwa, Ustroń 2010.

$$
\begin{array}{r}
\text { JÓZEF SUCHOŃ, Ph.D., Eng. } \\
\text { STANISEAWTYTKO, M.Sc., Eng. } \\
\text { jozek.suchon@gmail.com } \\
\text { stanislaw.tytko@kopex.com.pl } \\
\text { PAWEŁMENDYKA, M.Sc., Eng. } \\
\text { Department of Mining, Dressing } \\
\text { and Transport Machines }
\end{array}
$$

Faculty of Mechanical Engineering and Robotics AGH University of Science and Technology al. Mickiewicza 30, 30-059 Krakow, Poland mendyka@agh.edu.pl 
JÓZEF SUCHOŃ

STANISEAW TYTKO

PAWEE MENDYKA

\title{
Płynne sterowanie prędkością ścianowych przenośników zgrzebłowych w celu zwiększenia ich trwałości
}

\begin{abstract}
$W$ artykule przedstawiono koncepcję oraz zatożenia dotyczace płynnego sterowania prędkościa przenośnika zgrzebłowego, a na tej podstawie również kolejnych przenośników odstawy urobku wykorzystywanych w podziemnej kopalni węgla kamiennego. Przedstawiono niezbędne zależności umożliwiające dostosowanie prędkości ruchu przenośnika do utrzymania stałego przekroju poprzecznego strugi urobku, zarówno w przypadku urabiania jedno-, jak i dwukierunkowego. Szczególna uwage poświęcono obszarom, w których kombajn pracuje ze zmiennym zabiorem, czyli przy zawrębianiu kombajnu w caliznę węglowa na końcach wyrobiska ścianowego.
\end{abstract}

Słowa kluczowe: przenośnik zgrzebłowy, przenośnik ścianowy, sterowanie prędkościa, wyrobisko ścianowe, trwatość przenośnika

\section{WPROWADZENIE}

Wszystkie przenośniki zgrzebłowe pracujące obecnie w kombajnowych systemach ścianowych w kopalniach węgla kamiennego mają stałe prędkości ruchu cięgna łańcuchowego (z zastrzeżeniem wykorzystania napędów dwubiegowych dla potrzeb łatwiejszego rozruchu). Zmienność warunków pracy kombajnu w ścianie, technologia prowadzenia robót wydobywczych i współpraca $z$ maszynami oraz urządzeniami kompleksu ścianowego, podścianowego i dalszych środków odstawy urobku powodują, że praca przenośnika ścianowego, podścianowego oraz przenośników taśmowych charakteryzuje się dużą zmiennością wydajności, przez co stałoprędkościowy charakter pracy przenośnika ścianowego staje się niekorzystny ze względu na:

- znaczne skrócenie trwałości przenośników, liczonej w ilości przetransportowanego urobku od momentu rozpoczęcia pracy przenośnika do momentu wymiany jego poszczególnych elementów i zespołów,

- zwiększone zużycie energii elektrycznej,

- zwiększoną emisję ciepła i hałasu do atmosfery kopalnianej.

Rozwiązaniem tej niedogodności jest zmiana charakteru pracy przenośnika zgrzebłowego ze stałopręd- kościowej na zmiennoprędkościową. Konieczne przy tym jest zastosowanie w nowym układzie sterowania przemienników częstotliwości, które przez odpowiednio dobrane sygnały i algorytmy sterujące zapewnią takie automatyczne sterowanie prędkością ruchu cięgna przenośnika, aby został zapewniony stały przekrój urobku na przenośniku, przyjęty jako najkorzystniejszy.

Zastosowanie przemiennika częstotliwości daje również dodatkowe zalety związane $\mathrm{z}$ umożliwieniem łagodnego rozruchu i hamowania przenośnika zgrzebłowego. Obecnie najczęściej stosowanym urządzeniem ułatwiającym rozruch przenośnika jest dwubiegowy silnik elektryczny połączony ze sprzęgłem podatnym; istnieją również inne rozwiązania techniczne tego zagadnienia, takie jak sprzęgła hydrokinetyczne, rozruszniki tyrystorowe czy przekładnie CST. Szerzej temat ten przedstawiono w publikacji [1].

\section{WARUNKI ZASTOSOWANIA I STRUKTURA UKŁADU STERUJĄCEGO}

Po dokonaniu analizy pracy kombajnowego kompleksu ścianowego okazało się, że podczas pracy kombajnu ze stałym zabiorem warunkiem zastosowania sterowania prędkością ruchu cięgna łańcuchowego 
przenośnika ścianowego jest dostęp do dwóch zewnętrznych sygnałów sterujących, tj. prędkości ruchu kombajnu podczas urabiania i czyszczenia ścieżki pokombajnowej (przy urabianiu jednokierunkowym) oraz informacji o kierunku ruchu kombajnu (ruch zgodny lub przeciwny do ruchu cięgna łańcuchowego przenośnika ścianowego).

Ponieważ podczas zawrębienia się w caliznę węglową zabiór kombajnu zależy od położenia kombajnu wyznaczonego w stosunku od końca ściany, dla stabilizacji przekroju strugi urobku w tej fazie trzecim koniecznym sygnałem sterującym stało się położenie kombajnu w ścianie. $\mathrm{Z}$ tego powodu do prawidłowego działania systemu sterowania prędkością przenośnika niezbędna jest bądź to informacja zwrotna $\mathrm{z}$ wewnętrznych rejestratorów kombajnu o jego aktualnym położeniu, bądź instalacja zewnętrznych czujników i urządzeń określających to położenie. Koncepcja pomiaru przemieszczenia kombajnu względem punktu bazowego na podstawie impulsów z systemu posuwu została przedstawiona w dalszej części artykułu.

Do sterowania prędkością ruchu cięgna łańcuchowego ścianowego przenośnika zgrzebłowego w trakcie urabiania ze stałym zabiorem niezbędne są specjalne algorytmy sterowania, które w tym przypadku są zależnościami określającymi prędkości ruchu cięgna w funkcji następujących parametrów:

- prędkości posuwu kombajnu przy urabianiu i czyszczeniu ścieżki pokombajnowej (dla urabiania jednokierunkowego),
- kierunku ruchu kombajnu względem kierunku odstawy przenośnika ścianowego,

- efektywnego zabioru kombajnu,

- efektywnej wysokości urabiania,

- współczynnika rozluzowania węgla,

- najkorzystniejszego przekroju urobku na przenośniku,

- współczynnika określającego względną wartość (udział) urobku załadowanego na przenośnik ścianowy przez organy urabiające $\mathrm{w}$ trakcie urabiania jednokierunkowego.

Na rysunku 1 przedstawiono przykładowy system sterowania prędkością ścianowego przenośnika zgrzebłowego, zdatny do implementacji w warunkach przemysłowych. Dokładny opis takiego systemu wraz ze szczegółami dotyczącymi struktury oprogramowania układu został przedstawiony w publikacji [2]. Schemat układu sterowania prędkością przenośnika zgrzebłowego został oparty na sterowniku głównym (A1), sterowniku lokalnym (A2), przemiennikach częstotliwości - osobno dla napędu wysypowego (U1) i zwrotnego (U2), pulpicie sterującym (A4), napędach elektrycznych (M1-M3) oraz pomocniczym systemie łączności i blokad. Biorąc pod uwagę współpracę przenośnika z innymi urządzeniami kompleksu ścianowego oraz kolejnymi urządzeniami odstawy, system powinien być wyposażony również w urządzenia łączności ze sterownikami przenośnika podścianowego i przenośników taśmowych, jak również z nadrzędnym systemem sterowania.

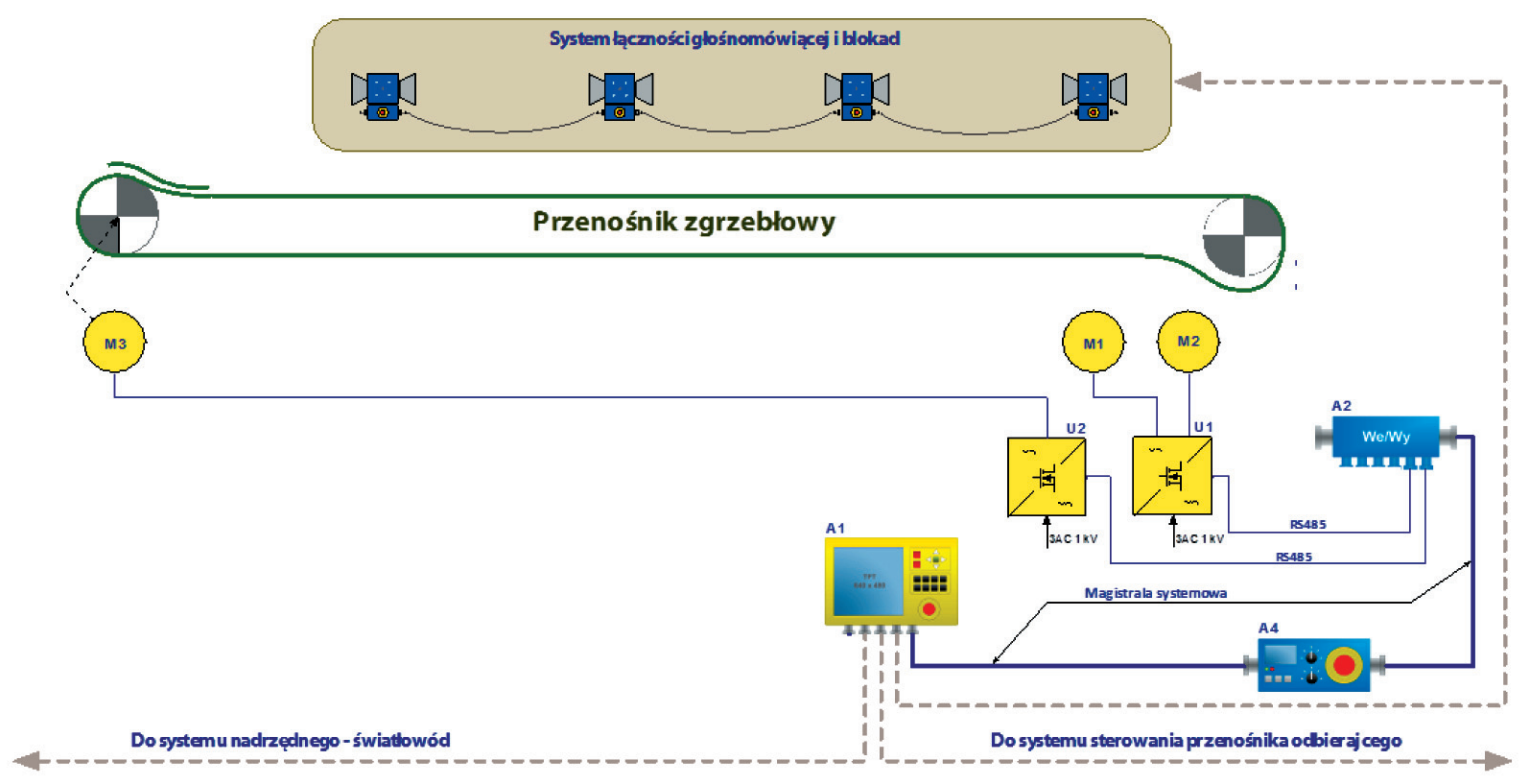

Rys. 1. Schemat układu sterowania prędkością ścianowego przenośnika zgrzebłowego: M1, M2 - silniki napędu wysypowego, M3 - silnik napędu zwrotnego, A1 - sterownik nadrzędny, A2 - sterownik lokalny,

A4 - pulpit sterowniczy, U1, U2 - przemienniki częstotliwości 


\section{MONITOROWANIE POZYCJI KOMBAJNU W WYROBISKU ŚCIANOWYM}

Ciągła informacja o położeniu kombajnu w ścianie jest potrzebna sterownikowi nadrzędnego przenośnika zgrzebłowego z następujących powodów:

- do określenia prędkości ruchu przenośnika w funkcji posuwu i wielkości zabioru kombajnu przy jego zawrębianiu się w caliznę węglową,

- jako pomoc przy sterowaniu pracą kombajnu odpowiednio do utrudnień i zagrożeń występujących w różnych miejscach ściany,

- jako przyczynek do pełnej automatyzacji pracy całego kompleksu ścianowego i poprawy bezpieczeństwa pracy.

Pozycjonowanie kombajnu w ścianie musi być dokładne, pozbawione błędu systematycznego, który mógłby z każdym przejściem kombajnu wzdłuż ściany powiększać błąd jego położenia. $\mathrm{Z}$ tego powodu przełożenie przekładni mechanizmu posuwu kombajnu potrzebne do określenia przemieszczenia kombajnu od przyjętego układu współrzędnych powinno być podawane jako teoretyczna zależność uwzględniająca liczby zębów wszystkich kół zębatych w przekładni, a nie, jak to się zwykle czyni, jako przybliżoną wartość przełożenia (przy błędzie przełożenia $0,1 \%$ jedno przejście przez ścianę długości $300 \mathrm{~m}$ daje błąd położenia kombajnu wynoszący $0,3 \mathrm{~m}$ ).
Przesunięcie kombajnu od położenia wyjściowego najlepiej jest określać przez liczbę obrotów wałka szybkobieżnego przekładni posuwu kombajnu. Drogę kombajnu określi wtedy zależność:

$$
L_{i}=\frac{n_{i}}{i_{c}} \cdot z_{k} \cdot p[\mathrm{~m}]
$$

gdzie:

$L_{i}$ - odległość koła trakowego od początku układu pomiarowego $[\mathrm{m}]$,

$n_{i}$ - liczba obrotów wałka szybkoobrotowego na drodze posuwu kombajnu,

$z_{k}$ - liczba zębów koła trakowego,

$p$ - podziałka systemu posuwu kombajnu [m],

$i_{c}$ - przełożenie całkowite przekładni $\mathrm{w}$ napędzie posuwu kombajnu.

Jeśli początek układu pomiarowego na przenośniku zostanie przyjęty w miejscu położenia osi koła trakowego kombajnu po stronie napędu wysypowego, gdy organ urabiający dokończy urabianie w górnej warstwie urabianego pokładu (punkt K), czyli $L_{i=0}=L_{0}$ (rys. 2), to ruch kombajnu w kierunku napędu zwrotnego powinien się zakończyć po osiągnięciu punktu K', czyli gdy kombajn wykona drogę:

$$
L_{k}=L_{S O}-A_{m r}-2 L_{r g}[\mathrm{~m}]
$$

Położenie punktu $L_{i=0}$ w początkowej fazie pracy kombajnu w ścianie (pierwsze skrawy) będzie się znajdowało w odległości od punktu $\mathrm{K}$ równej $L_{0}=L_{r g}+W$.

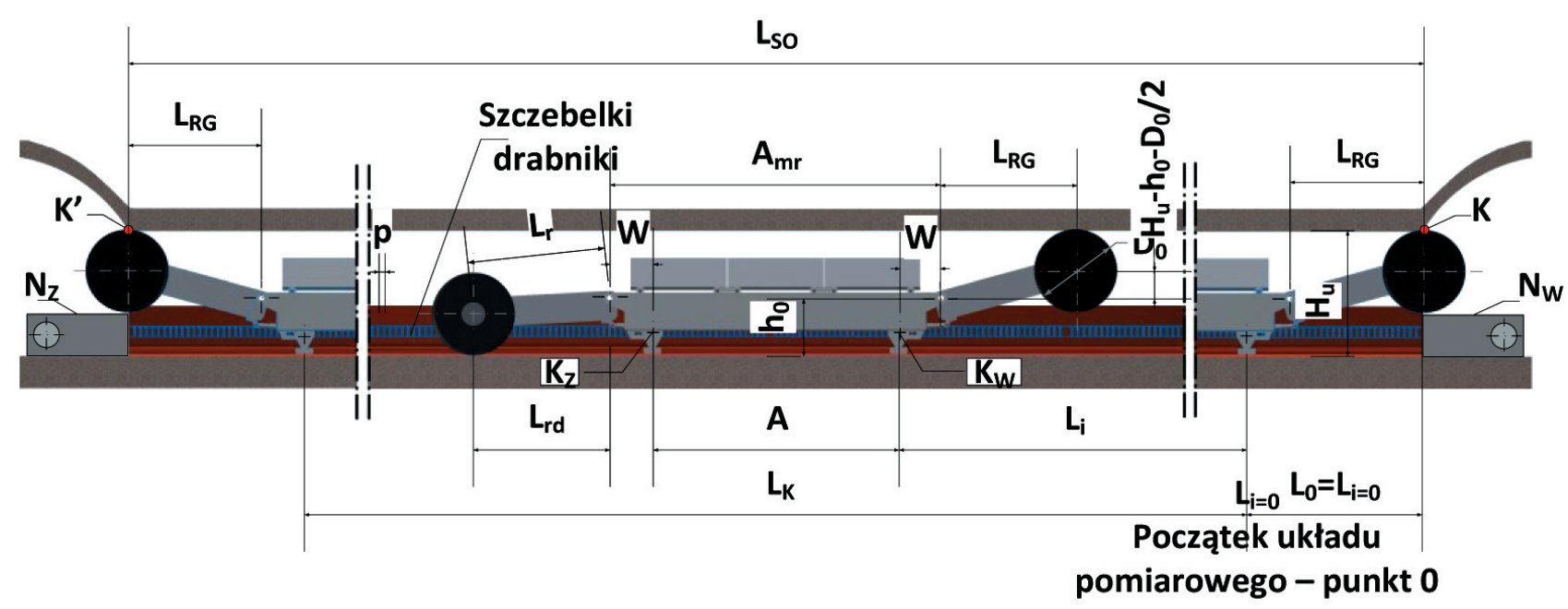

Rys. 2. Schemat do określania położenia kombajnu przy ruchu zgodnym z kierunkiem i przeciwnym do kierunku ruchu cięgna łańcuchowego przenośnika ścianowego: $N_{w}-$ napęd wysypowy, $N_{z}-$ napęd zwrotny, $K_{w}, K_{z}-$ kota systemu posuwu od strony napędu wysypowego i zwrotnego 
$\mathrm{Z}$ różnych względów ruchowych położenie punktu $\mathrm{K}$ względem przyjętego wcześniej punktu $L_{i=0}$ może się zmienić i wtedy $L_{0}-L_{r g}+W$. Takie sytuacje moga powstawać w pobliżu napędu wysypowego, zwrotnego lub nawet przy obu, gdy wstawia się lub wymontowuje rynny skrócone albo normalne (o nominalnej długości). Wtedy zależność (2) przyjmie postać:

$$
L_{k}=L_{S O}-A_{m r}-2 L_{r g} \pm L_{d w} \pm L_{d z}[\mathrm{~m}]
$$

gdzie:

$L_{k}$ - droga, jaka pokonuje kombajn w ścianie $[\mathrm{m}]$,

$L_{s o}$ - początkowa długość ściany [m],

$A_{m r}$ - rozstaw osi mocowania ramion kombajnu $[\mathrm{m}]$,

$L_{r g}$ - długość ramienia kombajnu w rzucie $[\mathrm{m}]$,

$L_{d w}, L_{d z}$ - długości dodane lub odjęte spowodowane przez dodanie lub odjęcie rynien w pobliżu napędu wysypowego i zwrotnego $[\mathrm{m}]$.

Długość ramienia w rzucie, czyli $L_{r g}$, określa zależność:

$$
L_{r g}=\sqrt{L_{r}^{2}-\left(H_{k}-H_{0}-0,5 D_{o}\right)^{2}}[\mathrm{~m}]
$$

gdzie:

$H_{k}$ - maksymalna wysokość urabiania [m],

$H_{o}$ - wysokość osi ramienia kombajnu od spągu [m].

$D_{o}$ - średnica organu urabiającego [m].
Położenie kombajnu w ścianie od punktu początkowego $L_{i=0}$ można dokładnie określać przez podawanie liczby podziałek systemu posuwu kombajnu, jaką on pokonał, czyli:

$$
N_{i}=\frac{L_{i}}{p}=\frac{n_{i} \cdot z_{k}}{i_{c}}
$$

Górnicy określają miejsce w ścianie w przybliżeniu przez podanie numeru sekcji obudowy zmechanizowanej liczonej od napędu wysypowego. Aby móc się posługiwać tą miarą, można skorzystać z zależności (rys. 3):

$$
S_{i}=\frac{N_{i}-N_{z}}{N_{r}}+S_{z}
$$

gdzie:

$S_{i}$ - numer sekcji określający przybliżone położenie kombajnu,

$N_{i}$ - liczba podziałek systemu posuwu kombajnu od punktu $L_{i=0}$,

$N_{z}$ - liczba podziałek systemu posuwu kombajnu od punktu $L_{i=0}$ do początku rynny,

$N_{r}$ - liczba podziałek systemu posuwu kombajnu przypadająca na rynnę normalną,

$S_{z}$ - liczba sekcji obudowy zmechanizowanej przy napędzie wysypowym o podziałce rozmieszczenia innej niż na trasie przenośnika.

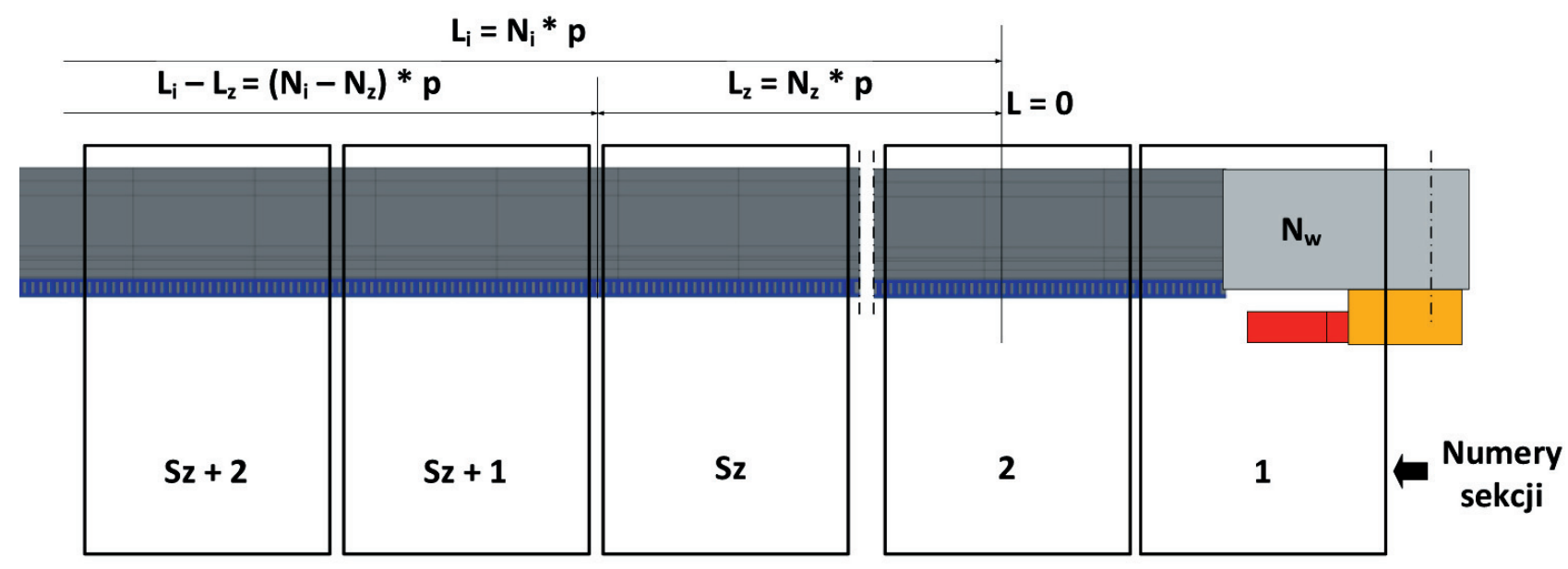

Rys. 3. Określenie przybliżonego położenia kombajnu $w$ ścianie przez podanie numeru sekcji obudowy zmechanizowanej na podstawie zliczonych impulsów $N_{i}$ 


\section{ZALEŻNOŚCI NIEZBĘDNE DO STEROWANIA PRĘDKOŚCIA RUCHU PRZENOŚNIKA W CZASIE PRACY KOMBAJNU ZE STAKYM ZABIOREM}

Objętość urobionej calizny i objętość (wydajność) urobku podają zależności [3]:

$$
\begin{aligned}
& Q=H_{u} \cdot Z \cdot v_{k}\left[\mathrm{~m}^{3} / \mathrm{s}\right] \\
& Q_{u}=Q \cdot \Psi=H_{u} \cdot Z \cdot v_{k} \cdot \Psi\left[\mathrm{m}^{3} / \mathrm{s}\right]
\end{aligned}
$$

gdzie:

$Q, Q_{u}$ - objętość urobionej calizny i objętość urobku $\left[\mathrm{m}^{3} / \mathrm{s}\right]$,

$H_{u}$ - wysokość urabiania [m],

$Z$ - zabiór kombajnu [m],

$v_{k}-$ prędkość posuwu kombajnu $[\mathrm{m} / \mathrm{s}]$,

$\Psi$ - współczynnik rozluźnienia $(\Psi=1,35 \div 1,4)$.

Prędkość łańcucha przenośnika ścianowego względem kombajnu określa zależność:

$$
v_{t s / k}=v_{t s} \pm v_{k}[\mathrm{~m} / \mathrm{s}]
$$

gdzie:

$v_{t s / k}$ - prędkość łańcucha przenośnika ścianowego względem kombajnu [m/s],

$v_{k}$ - prędkość posuwu kombajnu [m/s],

$v_{t s}$ - prędkość łańcucha przenośnika ścianowego $[\mathrm{m} / \mathrm{s}]$.

We wzorze (9) znak [+] należy przyjmować, gdy wektory prędkości kombajnu i łańcucha mają kierunki przeciwne (ruch kombajnu w kierunku napędu zwrotnego), zaś znak [-], gdy te wektory mają kierunki zgodne (ruch kombajnu w kierunku napędu wysypowego).

Przy urabianiu dwukierunkowym można przyjąć, że całość urobku przejmuje przenośnik i wtedy jego wydajność $Q_{s}$ jest równa:

$$
Q_{s}=Q_{u}=H_{u} \cdot Z \cdot v_{k}\left[\mathrm{~m}^{3} / \mathrm{s}\right]
$$

Zastępując rzeczywisty przekrój urobku na przenośniku $F_{S}$ równoważnym przekrojem prostokątnym (rys. 4), otrzymuje się zależność:

$$
F_{s}=b_{s} \cdot h\left[\mathrm{~m}^{2}\right]
$$

Przekrój ten jako nominalny $F_{S n}$ powinno się określać zgodnie z zależnością:

$$
F_{S n}=b_{s} \cdot h_{n}=\varphi_{s} \cdot b_{s}^{2}\left[\mathrm{~m}^{2}\right]
$$

gdzie $\varphi_{\mathrm{s}}=(0,4 \div 0,6)$.

\section{Ponieważ}

$$
Q_{u}=Q_{s}=F_{s n} \cdot v_{t s / k}\left[\mathrm{~m}^{3} / \mathrm{s}\right]
$$

to wykorzystując wzory (8), (9) i (12), otrzymuje się zależność:

$$
Q_{s}=Q_{u}=H_{u} \cdot Z \cdot v_{k} \cdot \Psi=\varphi_{s} \cdot b_{s}^{2} \cdot v_{t s / k}\left[\mathrm{~m}^{3} / \mathrm{s}\right]
$$

z której po przekształceniu otrzymuje się:

$$
\begin{aligned}
v_{t s} & =\frac{H_{u} \cdot Z \cdot v_{k} \cdot \Psi}{\varphi_{s} \cdot b_{s}^{2}}-\left( \pm v_{k}\right)= \\
& =v_{k} \cdot\left[\frac{H_{u} \cdot Z \cdot \Psi}{\varphi_{s} \cdot b_{s}^{2}}-( \pm 1)\right][\mathrm{m} / \mathrm{s}]
\end{aligned}
$$

Zależność (15) dla ruchu przeciwnego kombajnu, tj. w kierunku napędu zwrotnego przenośnika, przyjmie postać:

$$
v_{t s}=v_{k} \cdot\left[\frac{H_{u} \cdot Z \cdot \Psi}{\varphi_{s} \cdot b_{s}^{2}}-1\right]=k_{z p} \cdot v_{k}[\mathrm{~m} / \mathrm{s}]
$$

zaś dla ruchu zgodnego, tj. w kierunku napędu wysypowego przenośnika:

$$
v_{t s}=v_{k} \cdot\left[\frac{H_{u} \cdot Z \cdot \Psi}{\varphi_{s} \cdot b_{s}^{2}}+1\right]=k_{z z} \cdot v_{k}[\mathrm{~m} / \mathrm{s}]
$$

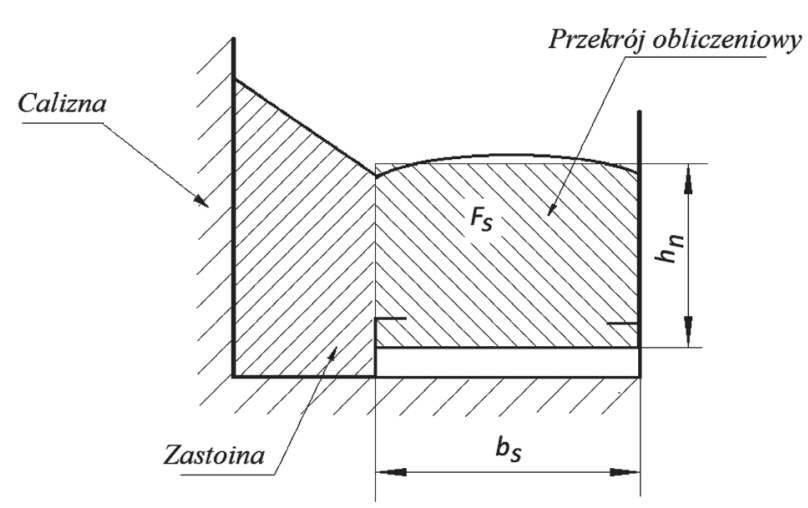

Rys. 4. Rzeczywisty i zastępczy przekrój poprzeczny urobku na rynnach ścianowego przenośnika zgrzebłowego 
Gdy kombajn urabia jednokierunkowo, to część urobku po urabianiu pozostaje w ścieżce pokombajnowej. Wtedy wydajność urobku załadowywanego przez kombajn na przenośnik $Q_{s j}$ określa zależność:

$$
Q_{s j}=Q_{u} \cdot k_{u}=k_{u} \cdot H_{u} \cdot Z \cdot \Psi\left[\mathrm{m}^{3} / \mathrm{s}\right]
$$

zaś wydajność załadunku urobku na przenośnik ze ścieżki pokombajnowej $Q_{r}$ wyniesie:

$$
Q_{r}=Q_{u}\left(1-k_{u}\right)\left[\mathrm{m}^{3} / \mathrm{s}\right]
$$

gdzie we wzorach (18) i (19) $k_{u}$ jest współczynnikiem określającym względną wartość (udział) urobku załadowanego na przenośnik w trakcie urabiania.

Postępując dalej podobnie jak przy urabianiu dwukierunkowym, można wyprowadzić odpowiednie zależności do sterowania prędkością ruchu przenośnika.

Przy urabianiu kombajnem w kierunku zgodnym (w kierunku napędu wysypowego) uzyskuje się zależność:

$$
v_{t s}=v_{k} \cdot\left[\frac{k_{u} \cdot H_{u} \cdot Z \cdot \Psi}{\varphi_{s} \cdot b_{s}^{2}}+1\right]=k_{1 z} \cdot v_{k}[\mathrm{~m} / \mathrm{s}]
$$

Przy urabianiu w kierunku przeciwnym zależność wygląda następująco:

$$
\begin{aligned}
v_{t s} & =v_{k} \cdot\left[\frac{k_{u} \cdot H_{u} \cdot Z \cdot \Psi}{\varphi_{s} \cdot b_{s}^{2}}-1\right]= \\
& =k_{1 p} \cdot v_{k}[\mathrm{~m} / \mathrm{s}]
\end{aligned}
$$

Przy powrotnej jeździe kombajnu załadowywany jest urobek leżący w ścieżce pokombajnowej. Zależności na $v_{t s}$ są tu następujące:

- dla ruchu zgodnego kombajnu

$$
\begin{aligned}
v_{t s} & =v_{k} \cdot\left[\frac{\left(1-k_{u}\right) \cdot H_{u} \cdot Z \cdot \Psi}{\varphi_{s} \cdot b_{s}^{2}}+1\right]= \\
& =k_{1 z p} \cdot v_{k}[\mathrm{~m} / \mathrm{s}]
\end{aligned}
$$

- dla ruchu przeciwnego

$$
\begin{aligned}
v_{t s} & =v_{k} \cdot\left[\frac{\left(1-k_{u}\right) \cdot H_{u} \cdot Z \cdot \Psi}{\varphi_{s} \cdot b_{s}^{2}}-1\right]= \\
& =k_{1 p o} \cdot v_{k}[\mathrm{~m} / \mathrm{s}]
\end{aligned}
$$

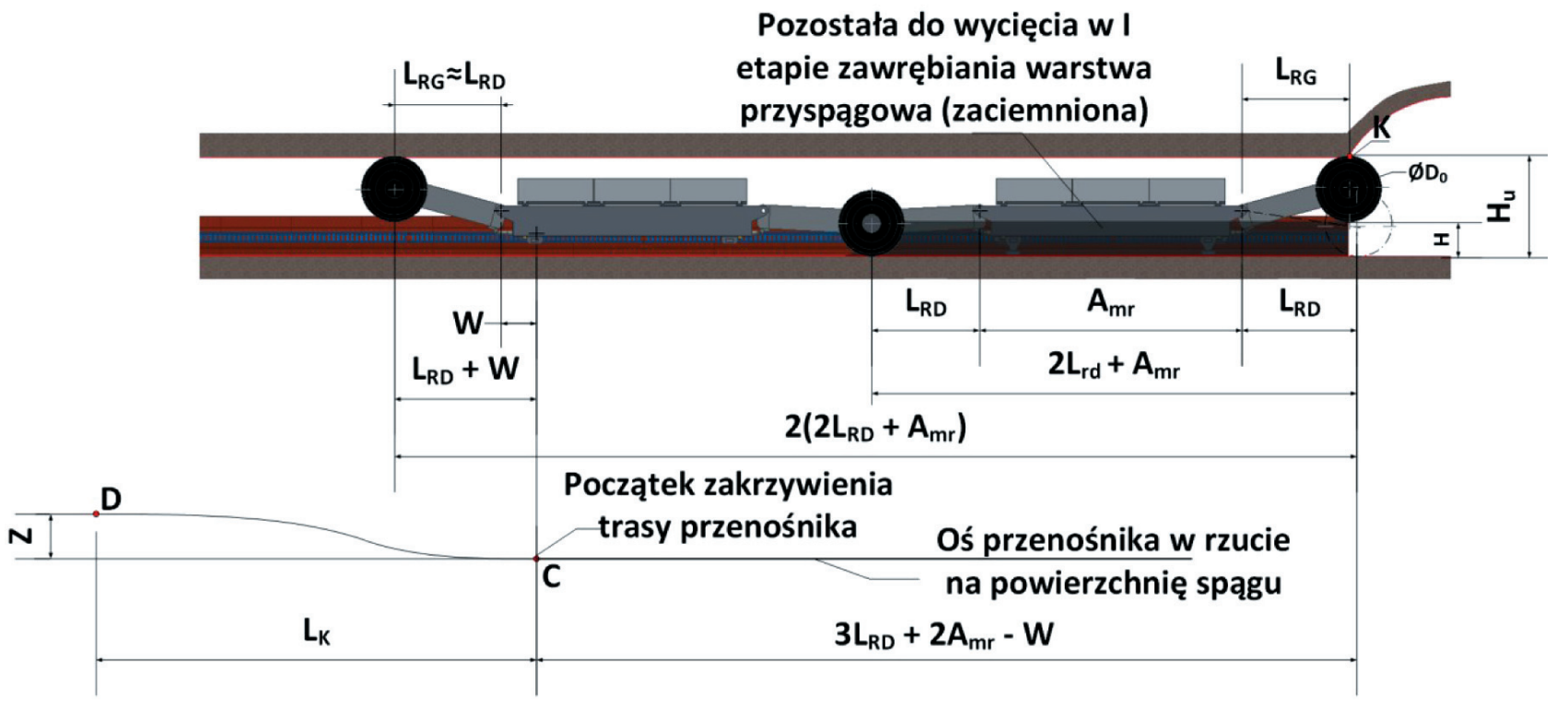

Rys. 5. Droga kombajnu przy urabianiu warstwy przyspagowej wegla oraz położenie organu górnego w momencie wchodzenia kombajnu na zakrzywienie przenośnika 
5. ZALEŻNOŚCI NIEZBĘDNE DO STEROWANIA PRĘDKOŚCIA RUCHU PRZENOŚNIKA W CZASIE URABIANIA WARSTWY PRZYSPAGOWEJ

Grubość warstwy przyspągowej zgodnie z rysunkiem 5 wynosi $H=H_{u}-D_{o}=k_{s u} \cdot H_{u}$. Postępując podobnie jak w pkt 3 , otrzymuje się zależności na $v_{t s}$ przy urabianiu warstwy przyspągowej przy napędzie wysypowym [2]:

$$
v_{t s}=v_{k} \cdot\left[\frac{k_{s u} \cdot H_{u} \cdot Z \cdot \Psi}{\varphi_{s} \cdot b_{s}^{2}}-1\right]=k_{2 p}^{\prime} \cdot v_{k}[\mathrm{~m} / \mathrm{s}]
$$

zaś przy takim samym urabianiu przy napędzie zwrotnym:

$$
v_{t s}=v_{k} \cdot\left[\frac{k_{s u} \cdot H_{u} \cdot Z \cdot \Psi}{\varphi_{s} \cdot b_{s}^{2}}+1\right]=k_{2 z}^{\prime} \cdot v_{k}[\mathrm{~m} / \mathrm{s}]
$$

gdzie $k_{s u}=H / H_{u}$ jest względną grubością warstwy przyspągowej.

\section{ZALEŻNOŚCI NIEZBĘDNE DO STEROWANIA PRĘDKOŚCIA RUCHU PRZENOŚNIKA PRZY PRACY KOMBAJNU \\ ZE ZMIENNYM ZABIOREM}

Przejście kombajnu przez zakrzywienie trasy przenośnika, z którym wiąże się zawrębianie kombajnu w caliznę, można podzielić w uproszczeniu na trzy fazy. Przykładowo przy zawrębianiu kombajnu w rejonie napędu wysypowego w fazie pierwszej, czyli przy przejściu koła trakowego $K_{z}$ od punktu $\mathrm{C}$ do $\mathrm{C}_{1}{ }^{\prime}$, przy którym koło $K_{z}$ przesunie się w kierunku calizny o około $0,25 Z$, kombajn przesunie się o $0,35 L_{k}$ (rys. 6). W czasie tego ruchu prędkość kombajnu może być jak przy wycinaniu warstwy przyspagowej.

W fazie drugiej, czyli na drodze od punktu $\mathrm{C}_{1}{ }^{\prime}$ do $\mathrm{C}_{2}$, ruch kombajnu odbywać się będzie z prędkością zmieniającą się liniowo, zależną od położenia kombajnu na zakrzywieniu. $\mathrm{W}$ punkcie $\mathrm{C}_{2}$ kombajn po przebyciu drogi $0,48 L_{k}$ osiągnie prędkość odpowiadającą pełnemu zabiorowi kombajnu. Do fazy tej po przekształceniu zależności (1) i wykorzystaniu faktu, że droga ze zmienną prędkością kombajnu odbywa się na odcinku $0,48 L_{k}$ uzyskuje się zależność:

$$
v_{t s}=v_{t C_{1}^{\prime}}+\frac{\Delta v_{t s}}{n_{C_{1}^{\prime}-C_{2}}}\left(n_{1}-n_{C_{1}^{\prime}}\right)[\mathrm{m} / \mathrm{s}]
$$

Uwzględniając, że:

$$
\Delta v_{t s}=\left(k_{z p}^{\prime}-k_{z p}\right) \cdot v_{k}[\mathrm{~m} / \mathrm{s}]
$$

oraz

$$
n_{C_{1}^{\prime}-C_{2}}=\frac{i_{C} \cdot 0,48 L_{k}}{z_{k} \cdot p}
$$

i podstawiając zależność (29), otrzymuje się (30):

$$
\begin{aligned}
& k_{j}=\frac{\left(k_{z p}^{\prime}-k_{2 p}^{\prime}\right)}{\frac{i_{C} \cdot 0,48 L_{k}}{z_{k} \cdot p}} \\
& v_{t s}=\left(k_{z p}^{\prime}+k_{j}\right) \cdot\left(n_{i}-n_{C_{1}}\right)[\mathrm{m} / \mathrm{s}]
\end{aligned}
$$

W fazie trzeciej od punktu $\mathrm{C}_{2}$ do $\mathrm{D}$, czyli na drodze $0,17 L_{k}$ i dalej na odcinku $\left(l_{r d}+A+W\right) v_{t k}$ powinno

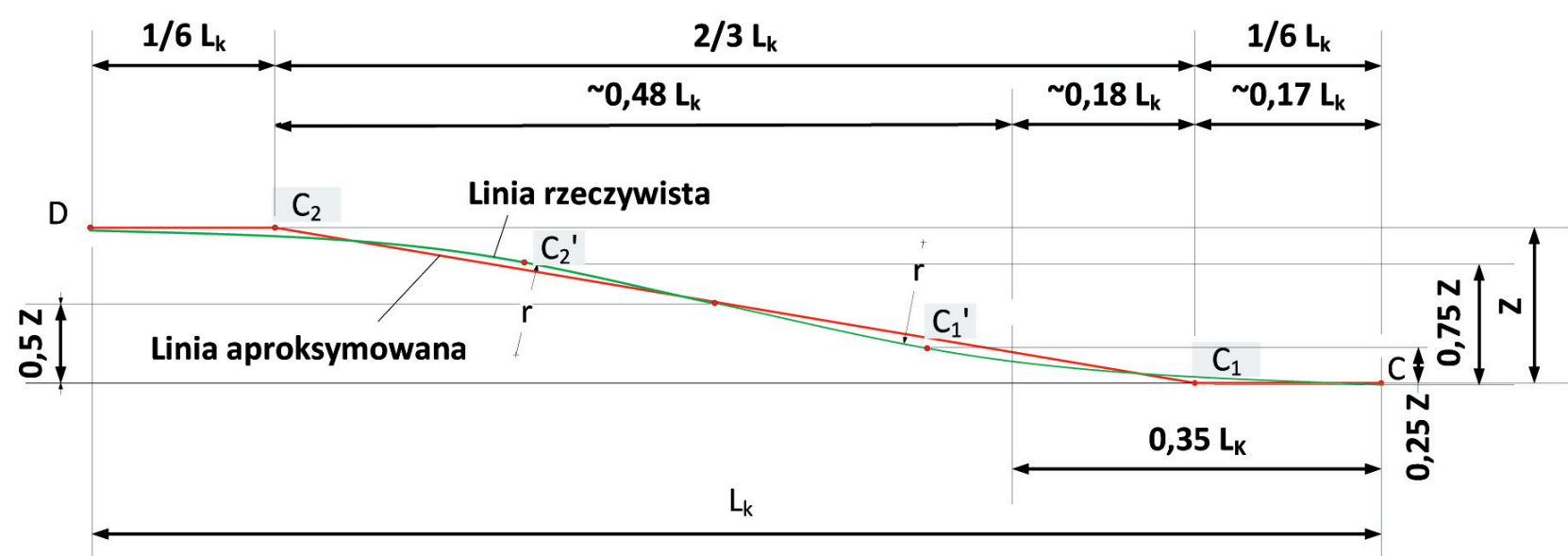

Rys. 6. Zastapienie rzeczywistej linii krzywizny przenośnika na odcinku zawrębiania kombajnu linia prosta $\mathrm{C}_{1}-\mathrm{C}_{-}-\mathrm{C}_{2}$ 
być jak na odcinku o stałym zabiorze, czyli $v_{t k}=k_{2 p} \cdot v_{k}$. Przejście przez kombajn odcinka $\left(l_{r d}+A a+W\right)$ jest konieczne, aby koło trakowe $K_{w}$ doszło do końca odcinka zakrzywionego i osiągnęło punkt D (rys. 6). W trakcie ruchu kombajnu przez zakrzywienie przenośnik od strony napędu wysypowego powinien być stopniowo dosuwany do czoła ściany, tak aby po osiągnięciu punktu D cały odcinek zakrzywienia przenośnika został wyprostowany.

\section{STEROWANIE KOLEJNYMI PRZENOŚNIKAMI W CIAZGU ODSTAWY UROBKU}

$\mathrm{Na}$ bazie sterowania prędkością ruchu przenośnika ścianowego bardzo łatwo jest już uruchomić sterowanie prędkością ruchu przenośnika podścianowego i dalszych ogniw odstawy urobku ze ściany, czyli przenośników taśmowych. W przypadku przenośnika podścianowego (rys. 7) [4] sygnałem sterującym

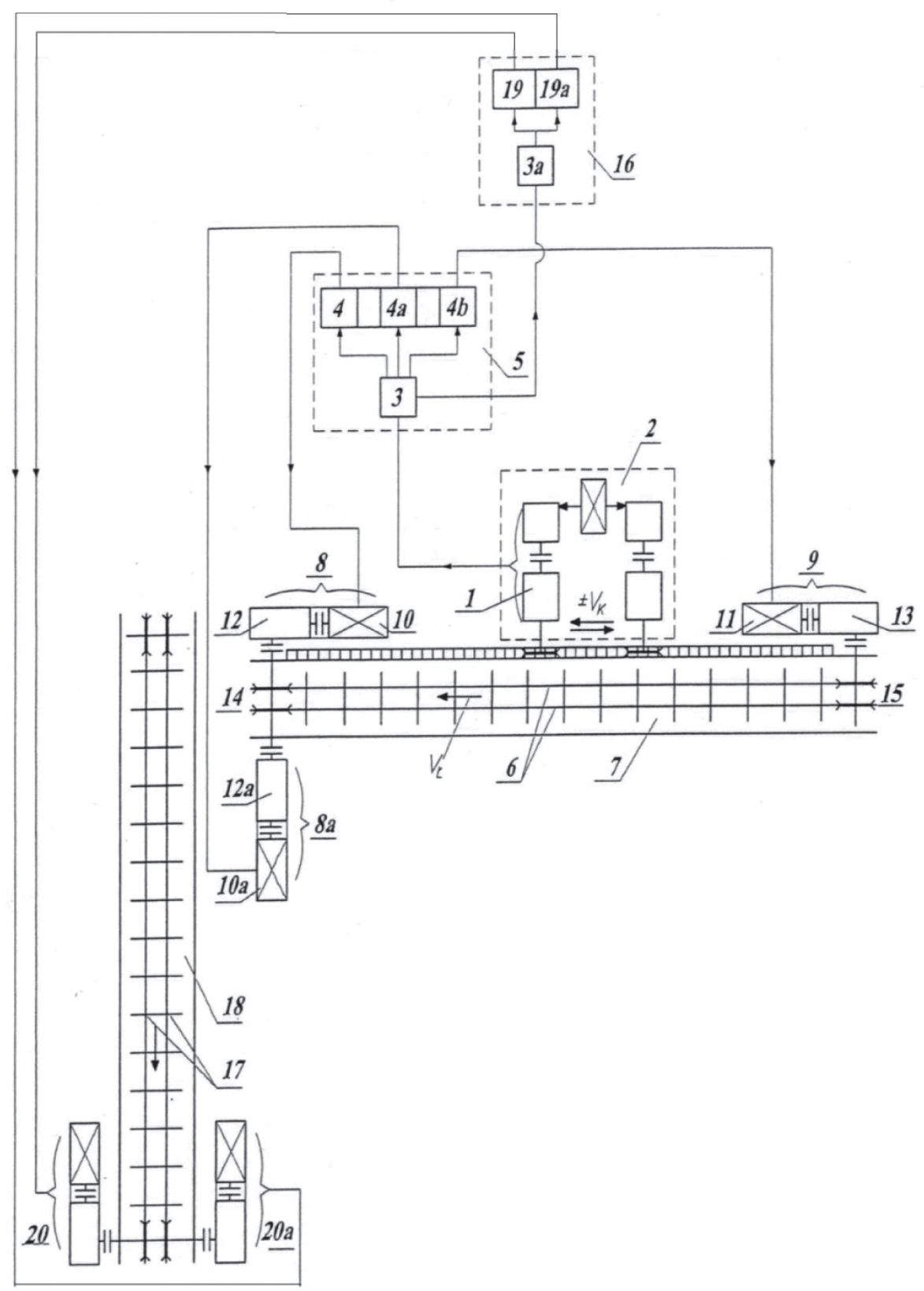

Rys. 7. Schemat sterowania prędkościa ruchu przenośnika podścianowego: 1 - przekładnia mechanizmu posuwu kombajnu, 2 - napęd posuwu kombajnu, 3 - sterownik ścianowego przenośnika zgrzebłowego, $3 a$ - sterownik podścianowego przenośnika zgrzebłowego, 4, 4a, 4b - przemienniki częstotliwości, 5 - zespót sterujący, 6 - cięgno tańcucha zgrzebłowego, 7 - ścianowy przenośnik zgrzebłowy, 8, 8a, 9 - jednostki napędowe, 10, 10a, 11 - silniki napędowe, 12, 12a, 13 - przektadnie, 14, 15 - bębny napędowe, 16 - zespót sterujący przenośnika podścianowego, 17 - cięgno tańcucha przenośnika podścianowego, 18 - podścianowy przenośnik zgrzebłowy, 19, 19a - przemienniki częstotliwości przenośnika podścianowego, 20, 20a - jednostki napędowe przenośnika podścianowego 
prędkością jego cięgna łańcuchowego będzie prędkość ruchu cięgna łańcuchowego przenośnika ścianowego.

Zależność między prędkością ruchu przenośnika ścianowego i podścianowego jest liniowa i ma charakter proporcjonalny zgodny z zależnością:

$$
v_{t p}=k_{p} \cdot v_{t s}[\mathrm{~m} / \mathrm{s}]
$$

gdzie:

$v_{t p}$ - prędkość ruchu przenośnika podścianowego $[\mathrm{m} / \mathrm{s}]$,

$v_{t s}-$ prędkość ruchu przenośnika ścianowego $[\mathrm{m} / \mathrm{s}]$,

$k_{p}$ - współczynnik prędkości ruchu przenośnika podścianowego względem przenośnika ścianowego.

Współczynnik $k_{p}$ jest wielkością określoną przez zależność:

$$
k_{p}=\frac{\varphi_{s} \cdot b_{s}^{2}}{\varphi_{p} \cdot b_{p}^{2}}
$$

gdzie:

$b_{s}$ - szerokość rynien przenośnika ścianowego [m],

$b_{p}$ - szerokość rynien przenośnika podścianowego $[\mathrm{m}]$,

$\varphi_{s}$ - względna wysokość ekwiwalentnej prostokątnej strugi urobku na ścianowym przenośniku zgrzebłowym $\left(\varphi_{s}=0,4-0,6\right)$,

$\varphi_{p}$ - względna wysokość ekwiwalentnej prostokątnej strugi urobku na przenośniku zgrzebłowym podścianowym $\left(\varphi_{p}=0,3-0,5\right)$.

Współczynniki $\varphi_{s}$ i $\varphi_{p}$ określają zależności:

$$
\varphi_{s}=\frac{h_{n s}}{b_{s}}
$$

$$
\varphi_{p}=\frac{h_{n p}}{b_{p}}
$$

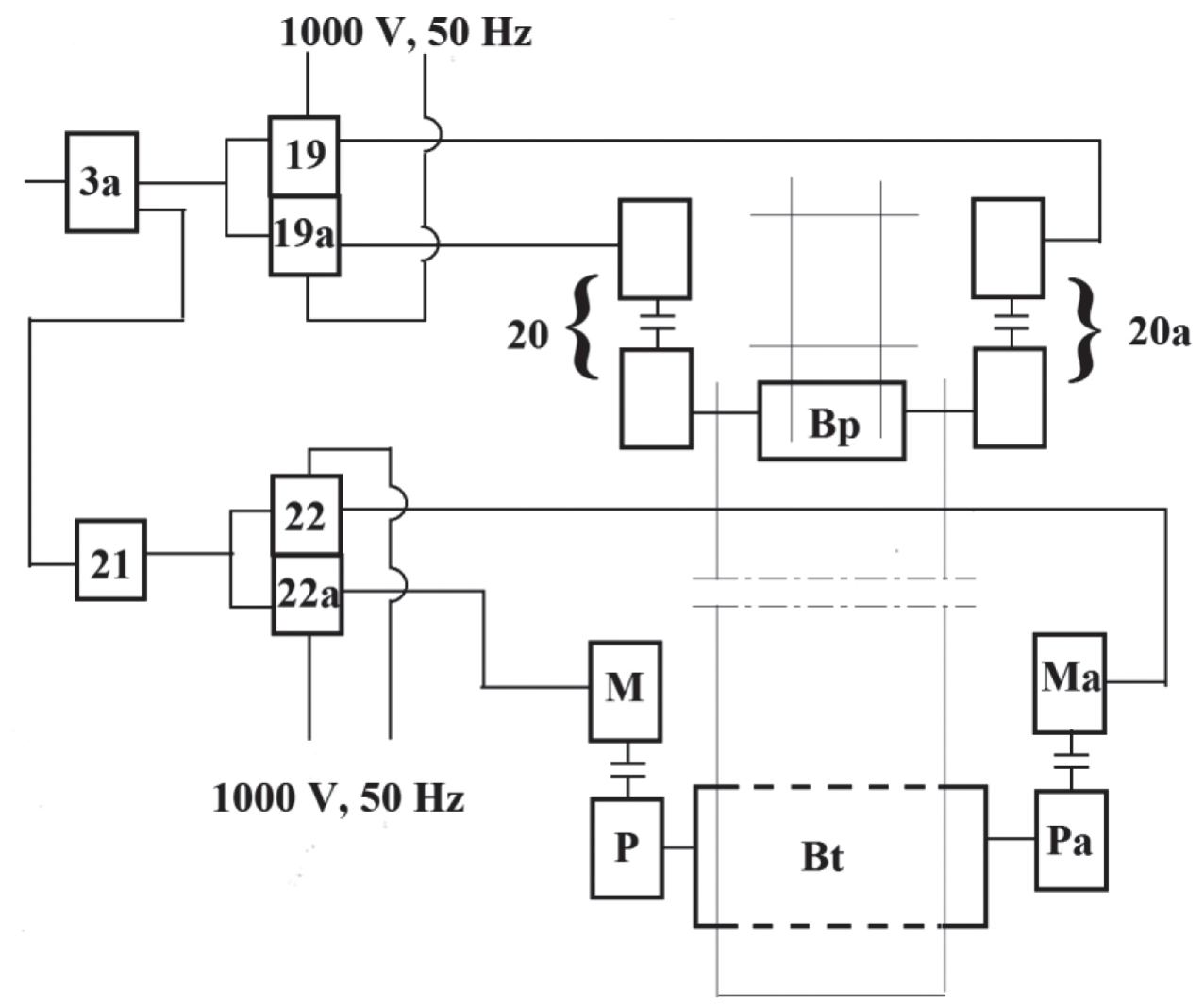

Rys. 8. Schemat sterowania prędkościa ruchu przenośnika taśmowego (w nawiązaniu do rys. 7): $3 a$ - sterownik podścianowego przenośnika zgrzebłowego 19, 19 a - przemienniki podścianowego przenośnika zgrzebłowego 20, 20 - jednostki napędowe podścianowego przenośnika zgrzebłowego, 21 - sterownik przenośnika taśmowego (lokalny). 22, 22a - przemienniki przenośnika taśmowego, M, Ma - silniki przenośnika taśmowego, P, Pa - przekładnie zębate napędu przenośnika taśmowego, Bp, Bt - bębny napędu podścianowego przenośnika zgrzebłowego i przenośnika taśmowego 
We wzorach (33) i (34) oznaczono przez:

$h_{n s}$ - nominalną wysokość ekwiwalentnej prostokątnej strugi urobku przenośnika ścianowego $[\mathrm{m}]$,

$h_{n p}$ - nominalną wysokość ekwiwalentnej prostokątnej strugi urobku przenośnika podścianowego $[\mathrm{m}]$.

Bazą do określenia prędkości ruchu taśmy przenośnika taśmowego odbierającego urobek z podścianowego przenośnika zgrzebłowego powinna być prędkość ruchu przenośnika podścianowego (rys. 8) zależna od prędkości ruchu przenośnika ścianowego. Bezpośrednie wykorzystanie sygnału z kombajnu nie jest celowe w odniesieniu do sterowania prędkością przenośnika taśmowego, podobnie jak przy sterowaniu prędkością ruchu przenośnika podścianowego, ponieważ należałoby stworzyć nowe skomplikowane algorytmy sterowania uwzględniające urabianie w ruchu zgodnym i przeciwnym przy urabianiu jedno- i dwukierunkowym.

Wykorzystanie sygnału z przenośnika podścianowego jest znacznie prostsze, ponieważ prędkość taśmy określa zależność (35):

$$
v_{t}=\frac{\varphi_{p} \cdot b_{p}^{2}}{k_{a} \cdot F_{n}} \cdot v_{t p}=k_{t} \cdot v_{t p}[\mathrm{~m} / \mathrm{s}]
$$

gdzie:

$v_{t}$ - prędkość ruchu przenośnika taśmowego [m/s],

$F_{n}$ - nominalny przekrój urobku przenośnika taśmowego [m],

$b_{p}$ - szerokość rynien przenośnika podścianowego $[\mathrm{m}]$

$v_{t p}$ - prędkość ruchu przenośnika podścianowego $[\mathrm{m} / \mathrm{s}]$,

$\varphi_{p}$ - względna wysokość ekwiwalentnej prostokątnej strugi urobku na zgrzebłowym przenośniku podścianowym,

$k_{a}$ - współczynnik prędkości ruchu przenośnika taśmowego względem podścianowego przenośnika zgrzebłowego.

Przedstawiony sposób sterowania prędkością ruchu przenośników taśmowych można wykorzystać do kontrolowania pracy kolejnych (dalszych) oddziałowych przenośników taśmowych. Możliwe jest też sterowanie tą metodą taśmowymi przenośnikami zbiorczymi, jednak przy aktualnym modelu eksploatacji węgla systemem podziemnym w Polsce przewidującym wydobycie $\mathrm{z}$ maksimum trzech ścian, i to $\mathrm{z}$ różnych rejonów i poziomów wydobywczych, rozpatrywanie takiego użycia jest niecelowe.

\section{UWAGI KOŃCOWE I PODSUMOWANIE}

Przedstawione w niniejszym artykule zależności pozwalają na takie sterowanie prędkością ruchu ścianowego przenośnika zgrzebłowego, aby w czasie jego pracy powierzchnia przekroju urobku na jego rynnach była w przybliżeniu stała. Jej wartość optymalną dla każdej ściany najkorzystniej jest wyznaczyć w warunkach ruchowych z uwzględnieniem prześwitu pod kombajnem, wielkości brył urobku, szerokości przenośnika, przyjętego systemu urabiania (urabianie jednokierunkowe, dwukierunkowe) i warunków górniczo-geologicznych. Względna, zastępcza wysokość strugi urobku $h$ odniesiona do szerokości rynien $h / b_{s}$ nie powinna przekraczać wartości 0,6 , ponieważ wtedy opory ruchu nadmiernie rosną, a ponadto średnia prędkość urobku wydatnie zmniejsza się w odniesieniu do prędkości ruchu łańcucha, co czyni transport bardziej energochłonnym i mniej efektywnym wydajnościowo.

Program sterowania prędkością przenośnika można realizować w różny sposób. Może to być jeden program obejmujaccy wszystkie etapy pracy kombajnu w ścianie przy urabianiu jedno- i dwukierunkowym lub np. osobno dla obu tych systemów urabiania. Wydaje się też potrzebne, aby kombajnista miał możliwość ręcznego sterowania pracą kombajnu i przenośnika w sytuacji awarii automatycznego sterowania prędkością przenośnika.

Ważnym zagadnieniem, które trzeba uwzględnić przy wykonywaniu programów sterowania prędkością przenośnika, jest problem jego prędkości w sytuacji krótkiego postoju kombajnu, a system odstawy urobku jest sprawny. Z wcześniej podanych zależności wynika potrzeba jego zatrzymania, jednak nie wydaje się to właściwe $\mathrm{z}$ uwagi na powstałą zwłokę i bezpieczeństwo pracy górników. Takie częste działania powodują skracanie efektywnego czasu pracy ściany i obniżają wydobycie. $\mathrm{Z}$ tego powodu wydaje się celowe, aby przenośnik nie zatrzymywał się, lecz przechodził do pracy z prędkością wleczoną, np. równą 10\% prędkości nominalnej. Do dyskusji jest też interwał czasowy tego ruchu.

Wprowadzenie analizowanego systemu sterowania prędkością przenośnika ścianowego umożliwia łatwe sterowanie prędkością ruchu dalszych przenośników odstawy urobku. Wymaga to jednak zastosowania w nich napędów o regulowanej prędkości.

Wstępne analizy wynikające $\mathrm{z}$ obserwacji ruchowych skłaniają do sugestii, że wprowadzenie do ruchu proponowanego systemu sterowania może zwiększyć trwałość elementów przenośnika (liczoną ilością 
przetransportowanego urobku do momentu wycofania z użytkowania) do około $25 \%$. Można też się spodziewać zmniejszenia energochłonności transportu na podobnym poziomie.

\section{Podziękowania}

Publikacja opracowana w ramach projektu badawczego INNOTECH-K1/IN1/158914/NCBR/12 „Energooszczędny system sterowania prędkością przenośników odstawy zwiększający ich trwałość", finansowanego ze środków Narodowego Centrum Badań i Rozwoju NCBiR.

\section{Literatura}

[1] Mendyka P.: Układy rozruchowe ścianowych przenośników zgrzeblowych, „Napędy i Sterowanie” 2014, 16, 7/8: 138-144.

[2] Gospodarczyk P., Stopka G., Mendyka P.: Projekt i badania ścianowego przenośnika zgrzebłowego o zmiennej prędkości ruchu, w: Mechanizacja, automatyzacja i robotyzacja w górnictwie, red. nauk. K. Krauze, Centrum Badań i Dozoru Górnictwa Podziemnego, Kraków - Lędziny 2014: 223-233.
[3] Suchoń J.: Górnicze przenośniki zgrzebłowe. Teoria, badania i eksploatacja, Instytut Techniki Górniczej, Gliwice 2012.

[4] Suchoń J., Tytko S.: Nowe propozycje RFM „RYFAMA” S.A. $w$ zakresie budowy $i$ sterowania ruchem ścianowych przenośników zgrzebłowych, „V Szkoła Mechanizacji i Automatyzacji Górnictwa”, Ustroń 2010.

dr inż. JÓZEF SUCHOŃ mgr inż. STANISŁAW TYTKO

jozek.suchon@gmail.com stanislaw.tytko@kopex.com.pl

mgr inż. PAWEŁ MENDYKA

Katedra Maszyn Górniczych, Przeróbczych $i$ Transportowych Wydziat Inżynierii Mechanicznej i Robotyki AGH Akademia Górniczo-Hutnicza im. Stanisława Staszica $w$ Krakowie al. Mickiewicza 30, 30-059 Kraków mendyka@agh.edu.pl 